Flávio Romero Palma

Investigação dos fenótipos e efeitos da expressão da proteína VAPB humana em Saccharomyces cerevisiae como modelo para Esclerose Lateral Amiotrófica

Investigation of phenotypes and effects of human VAPB protein expression in Saccharomyces cerevisiae as a model for Amyotrophic Lateral Sclerosis

São Paulo

2016 
Flávio Romero Palma

\title{
Investigação dos fenótipos e efeitos da expressão da proteína VAPB humana em Saccharomyces cerevisiae como modelo para Esclerose Lateral Amiotrófica
}

\author{
Investigation of phenotypes and effects of human VAPB \\ protein expression in Saccharomyces cerevisiae as a model \\ for Amyotrophic Lateral Sclerosis
}

Tese apresentada ao Instituto de Biociências da Universidade de São Paulo, para a obtenção de Título de Doutor em Ciências, na Ârea de Biologia/Genética.

Orientador (a): Prof. Dr. Luis Eduardo Soares Netto

São Paulo

2016 


\section{RESUMO}

A Esclerose Lateral Amiotrófica é uma doença neurodegenerativa que afeta seletivamente neurônios motores. A maior parte dos casos de ELA (90\%) é esporádica. Para os casos familiais, mais de vinte genes já foram associados. Diversos mecanismos estão envolvidos na patogênese, entre eles o estresse oxidativo, proteostase e agregação, excitoxicidade, tráfego intracelular, entre outros. A mutação P56S na proteína VAPB está associada à ELA8. A VAPB é uma proteína de membrana do retículo endoplasmático e está possivelmente envolvida em diversas funções celulares, dentre elas tráfego intracelular, interação retículo endoplasmático-aparelho de Golgi e UPR. Sabendo que mutações no gene que codifica VAPB resultam em ELA e que indivíduos com a mesma mutação neste gene podem apresentar quadros clínicos bastante diferentes, propõe-se estudar a suscetibilidade ao estresse oxidativo e ao estresse do retículo endoplasmático e as possíveis vias de degradação das proteínas mutantes como fatores subjacentes a essa heterogeneidade clínica. Desta forma, objetivou-se realizar uma análise integrada de ELA8, buscando compreender os mecanismos moleculares envolvidos na doença, utilizando a levedura Saccharomyces cerevisiae como modelo para estudo. Foram obtidas diferentes linhagens BY4741 de S. cerevisiae, expressando os genes de $V A P B^{W T}$ e $V A P B^{P 56 S}$ ou o plasmídeo vazio (que foi utilizado como controle em todos os experimentos) sob controle do promotor GAL1. Foram avaliadas as viabilidades das células expressando as proteínas humanas, a sua localização celular e possível formação de agregados. Os resultados mostram que a expressão da proteína $\mathrm{VAPB}^{\mathrm{P} 56 \mathrm{~S}}$ é tóxica e leva à formação de agregados dispersos nas células, enquanto a expressão da proteína selvagem se concentra no retículo endoplasmático e não altera significativamente a viabilidade das células. Scs2 é a proteína de levedura homóloga a VAPB, e a deleção do gene correspondente gera linhagens auxotróficas para inositol. $\mathrm{VAPB}^{\mathrm{WT}}$ e $\mathrm{VAPB}^{\mathrm{P} 56 \mathrm{~S}}$ foram expressas em linhagem nocaute para o gene $S c s 2$, a fim de analisar se os homólogos humanos complementam a auxotrofia a inositol. Observou-se que a linhagem expressando a proteína selvagem é capaz de restaurar o fenótipo selvagem e a linhagem expressando a proteína mutante não. Para avaliar os efeitos de estresse oxidativo nas linhagens BY4741, foram determinados: a viabilidade e sensibilidade das linhagens sob condições de estresse induzido por $\mathrm{H}_{2} \mathrm{O}_{2}$, a razão GSH/GSSG e a produção de $\mathrm{H}_{2} \mathrm{O}_{2}$ por mitocôndrias, além da viabilidade após tratamento com o antioxidante N-acetil-L-cisteína. De modo geral foi verificado que a linhagem expressando a proteína mutante é discretamente mais sensível ao tratamento com $\mathrm{H}_{2} \mathrm{O}_{2}$, possui menor razão GSH/GSSG, e produz mais $\mathrm{H}_{2} \mathrm{O}_{2}$ 
em mitocôndrias isoladas. Em conjunto, estes dados sugerem alteração no metabolismo redox a partir da expressão de $\mathrm{VAPB}^{\mathrm{P} 56 \mathrm{~S}}$. Os efeitos da inibição do proteassomo ( $\left.\Delta P d r 5+\mathrm{MG} 132\right)$ e da autofagia ( $\triangle A \operatorname{tg} 8)$ foram avaliados em ensaios de viabilidade e degradação proteica. Verificou-se que a inibição do proteassomo tem maior efeito sobre a viabilidade das linhagens expressando $\mathrm{VAPB}^{\mathrm{WT}}$ e diminui a degradação desta proteína. A inibição da autofagia, ao contrário, afeta mais a linhagem expressando $\mathrm{VAPB}^{\mathrm{P} 56 \mathrm{~S}}$. A atividade do proteassomo, a ubiquitinação de proteínas e os níveis de autofagia também foram avaliados, sendo verificado que há maior expressão de subunidades do proteassomo nas linhagens expressando ambas as proteínas. Na linhagem expressando VAPB ${ }^{\mathrm{WT}}$, observou-se maior atividade do proteassomo e uma diminuição no pool de proteínas ubiquitinadas, de acordo com a maior expressão de subunidades do proteassomo. Na linhagem expressando VAPB ${ }^{\text {P56s }}$, ao contrário, há diminuição da atividade do proteassomo e acúmulo de proteínas ubiquitinadas, sugerindo uma inibição do proteassomo. Por meio do monitoramento da fusão GFP-Atg8 foi verificada a maior formação de autofagossomos nas linhagens expressando $\mathrm{VAPB}^{\mathrm{P} 56 \mathrm{~S}}$, o que sugere maiores níveis de autofagia. Foi avaliada a viabilidade das células sob o efeito do aumento da expressão de Tsa1, uma peroxirredoxina com capacidade de recrutar chaperonas para agregados de forma redox dependente. Observou-se que esta proteína é capaz de atenuar a toxicidade de $\mathrm{VAPB}^{\mathrm{P} 56 \mathrm{~S}}$, especialmente no ensaio de diluição seriada. Por fim foram verificados os níveis de marcadores de estresse do retículo endoplasmático, Pdi1, Ero1, Lhs1 e Kar2, e de UPR, ${ }^{\mathrm{S}} \mathrm{Hac1}$, e foi visto que a expressão da proteína mutante alterou todos estes indicadores. Os dados em conjunto sugerem alterações no metabolismo redox e na proteostase resultantes da expressão de VAPB ${ }^{\mathrm{P} 56 \mathrm{~S}}$. 
Amyotrophic Lateral Sclerosis (ALS) is a neurodegenerative disease that affects motor neurons. The majority of ALS cases (90\%) are sporadic. More than twenty genes have been associated with familial cases. Several mechanisms are involved in ALS pathogenesis, including oxidative stress, proteostasis and aggregation, excitotoxicity, intracellular trafficking, and others. The P56S mutation in the protein VAPB is associated with ALS8. VAPB is a membrane protein of the endoplasmic reticulum that is possibly involved in diverse cellular functions, including intracellular trafficking, interaction endoplasmic reticulum-Golgi and UPR. Knowing that mutations in the gene encoding VAPB result in ALS and that individuals with the same mutation in this gene can show different clinical conditions, we aimed to analyze the susceptibility to oxidative and endoplasmic reticulum stresses and protein degradation pathways as factors underlying this clinical heterogeneity. Thus, the objective was to perform an integrated analysis of ALS8, trying to understand the molecular mechanisms involved in the disease using, for this purpose, budding yeast Saccharomyces cerevisiae was employed as a model for this study. Different strains of $S$. cerevisiae containing the gene $\mathrm{VAPB}^{\mathrm{WT}}$ or $\mathrm{VAPB}^{\mathrm{P} 56 \mathrm{~S}}$ or the empty plasmid were obtained. BY4741 strains were evaluated for their viability when expressing human proteins, the subcellular localization of these proteins and the ability to form aggregates. The results show that the expression of the mutant protein is toxic and leads to the formation of disperse aggregates in the cell, while the expression of the wild-type protein is concentrated in the endoplasmic reticulum and does not alter cell viability. Scs2 is the yeast homologue of VAPB and deletion of the corresponding gene renders cells auxotrophic for inositol. Therefore, $\mathrm{VAPB}^{\mathrm{WT}}$ and $\mathrm{VAPB}^{\mathrm{P} 56 \mathrm{~S}}$ genes were expressed in $\Delta s c s 2$ cells to evaluate their ability to complement the inositol auxotrophy. The strain expressing the wild-type protein was able to restore the wild type phenotype, while the strain expressing the mutant protein was not. To evaluate oxidative stress in BY4741 strains expressing human proteins, it was determined: viabilities and sensitivities to stress induced by $\mathrm{H}_{2} \mathrm{O}_{2}$; GSH /GSSG ratio and $\mathrm{H}_{2} \mathrm{O}_{2}$ production in the mitochondria, as well as viabilities after treatment of cells with $\mathrm{N}$-acetyl-L-cysteine. In general, it was found that the strain expressing the mutant protein is slightly sensitive to treatment with $\mathrm{H}_{2} \mathrm{O}_{2}$, had minor GSH/GSSG ratio, which indicates more oxidative cellular environment, and has a major production of $\mathrm{H}_{2} \mathrm{O}_{2}$ in isolated mitochondria. Together, these data suggest important changes in the redox metabolism associated with $\mathrm{VAPB}^{\mathrm{P5} 6 \mathrm{~S}}$ expression. The effects of inhibition of the proteasome $(\Delta P d r 5+$ MG132) and autophagy 
$(\triangle A \operatorname{tg} 8)$ were evaluated through viability assays and protein degradation. Inhibition of the proteasome had a greater effect on the viability of strains expressing VAPB ${ }^{\mathrm{WT}}$ and decreased the degradation of this protein. Inhibition of autophagy, in contrast, mainly affected the strain expressing $\mathrm{VAPB}^{\mathrm{P} 56 \mathrm{~S}}$. The activity of the proteasome, protein ubiquitilation and autophagy levels were evaluated in BY4741 strains expressing human proteins. We found an increased expression of proteasome subunits in the strains expressing both proteins, which lead to an increased activity of proteasome in $\mathrm{VAPB}^{\mathrm{WT}}$ strain and a decrease in the pool of ubiquitilated proteins. In strain expressing $\mathrm{VAPB}^{\mathrm{P} 56 \mathrm{~S}}$ instead, there is a reduced proteasome activity and accumulation of ubiquitilated proteins. By monitoring the GFP-Atg8 fusion, it was verified that the formation of autophagosomes was increased in strains expressing $\mathrm{VAPB}^{\mathrm{P} 56 \mathrm{~S}}$, suggesting higher levels of autophagy. The effect of Tsal expression, a peroxiredoxin capable to recruit chaperone to aggregates, on cell viability was evaluated and it was observed that this protein was able to attenuate the toxicity of VAPB ${ }^{\mathrm{P} 56 \mathrm{~S}}$. Finally the levels of endoplasmic reticulum stress markers, Pdi1, Ero1, Lhs1 and Kar2, and the UPR marker, ${ }^{S} \mathrm{Hacl}$, were checked and it was found that the expression of the mutant protein is able to change all these indicators. Taken together, our data suggest changes in the redox metabolism and proteostasis linked to $\mathrm{VAPB}^{\mathrm{P} 56 \mathrm{~S}}$ expression. 


\section{INTRODUÇÃO}

\section{Doença do Neurônio Motor e Esclerose lateral Amiotrófica}

\subsection{Histórico e epidemiologia}

As doenças do neurônio motor (DNM) formam um grupo de enfermidades neurodegenerativas caracterizadas pela perda prioritária de neurônios motores, levando à atrofia muscular progressiva, e cujo diagnóstico ocorre, na maioria das vezes, em fase tardia da progressão da doença (SHETTY et al., 2015). As principais DMNs são a Esclerose Lateral Amiotrófica (ELA), a Paralisia Bulbar Progressiva (PBP), Esclerose Lateral Primária (ELP), Atrofia Muscular Progressiva (AMP) e Atrofia Muscular Espinhal (AME) (CHIEIA, 2005). Estas doenças, apesar de apresentarem sintomas semelhantes, afetam diferentes tipos de neurônios motores - neurônios motores superiores (NMS) ou neurônios motores inferiores (NMI) - e possuem características genéticas distintas (Tabela 01).

Tabela 01. Doenças do neurônio motor

\begin{tabular}{c|cc} 
Doença & Neurônios afetados & Genes associados \\
ELA & NMS do córtex motor e NMI da medula e tronco cerebral & Mais de 30 \\
PBP & NMI do tronco cerebral & Ausente \\
ELP & NMS dos braços, pernas e face & Ausente \\
AMP & NMI & Ausente \\
AME & NMI & $S M N 1$ e SMN2 \\
\hline
\end{tabular}

A ELA é a mais comum DNM. Foi descrita em 1869 pelo neurologista francês JeanMartin Charcot e, portanto, é também conhecida como Doença de Charcot, ou ainda como Doença de Lou Gehrig (WiJESEKERA \& LEIGH, 2009).

A perda dos NMSs do córtex motor e dos NIMs da medula e tronco cerebral leva à fraqueza e atrofia muscular, fasciculações e espasticidade. Os sintomas e sinais surgem quando falham as conexões axonais, isto é, quando o axônio se retrai e ocorre a denervação dos NMI ou do músculo. Inicialmente, esta retração é compensada pela reinervação de axônios dos neurônios mais resistentes ao processo degenerativo. No entanto, com a progressão da doença, este mecanismo compensatório se torna insuficiente. É somente após 
esta fase inicial de disfunção e retração axonal que o corpo celular neuronal torna-se visivelmente anormal e morre (ROBBERECHT \& PHILIPS, 2013). Neurônios do córtex préfrontal e do córtex temporal podem ser afetados em diferentes graus, resultando em uma disfunção frontal em muitos pacientes com este transtorno e concomitante demência frontotemporal (DFT) em cerca de 15\% dos pacientes. Esta situação é conhecida como esclerose lateral amiotrófica com a degeneração do lobo fronto-temporal (ELA-DFT) (RINGHOLZ et al., 2005).

A incidência mundial de ELA atinge 1,9/100.000 indivíduos e a prevalência estimada é de 4,48/100.000 indivíduo (CHIÒ et al., 2013). Alguns locais, como a ilha Guam e a Península de Kii no Japão, possuem prevalência de 50 a 100 vezes maior do que em outras partes do mundo (Plato et al., 2003; KuZUhara et al., 2001).

A incidência de ELA é maior em homens que em mulheres, com uma relação masculino-feminino geral de 1,5-2 homens para cada mulher afetada. Após a idade de 65 anos, a incidência entre homens e mulheres é igual (ARMON, 2003).

As primeiras manifestações podem ocorrer desde a adolescência até o final da oitava década de vida, mas o pico de aparecimento dos sintomas ocorre aos 55 anos (PASINELLI \& BRown, 2006). A sobrevivência média é de 3-5 anos após o início dos sintomas. No entanto, maior sobrevida não é rara. Cerca de $15 \%$ dos pacientes com ELA vivem até 5 anos após o diagnóstico e cerca de 5\% sobrevivem por mais de 10 anos (ZALDIFAR et al., 2009).

Não há cura para a ELA até o momento. O Riluzol, um possível antagonista do glutamato, é o único medicamento aprovado para o tratamento de ELA, mas o mecanismo exato de ação do riluzol ainda é incerto (LACOMBLEZ et al., 1996). Seus efeitos prolongam a sobrevivência dos pacientes de ELA de dois a três meses, em média, apresentando, porém, um número considerável de efeitos colaterais adversos (BRYSON et al., 1996).

\subsection{Fatores genéticos ligados à ELA}

Aproximadamente $90 \%$ dos casos de ELA são esporádicos (ELAe) e os $10 \%$ restantes são familiais (ELAf). Em ELAe cerca de $10 \%$ dos casos foram associados a algum gene, entre eles alguns envolvidos em ELAf (Tabela 02). Os 90\% restantes possivelmente apresentam fatores ambientais associados (MARANGI \& TRAYNOR, 2014). Dados epidemiológicos revelam que alguns dos fatores possivelmente envolvidos em ELAe são o tabagismo (ARMON, 2009), baixa massa corporal e alto condicionamento físico (TURNER, 2013), atividade física vigorosa e esportes de alto impacto (LEHMAN et al., 2012), exposição a 
pesticidas (KAMEL et al., 2012) e exposição a metais, como o chumbo (KAMEL et al., 2003), manganês (Roos et al., 2012) e ferro (KWAN et al., 2012).

Tabela 02. Genes associados a ELA esporádica

\begin{tabular}{ccc} 
Gene & Locus & Associado à ELAf \\
$A P E X 1$ & $14 \mathrm{q} 11.2$ & Não \\
$H F E$ & $6 \mathrm{p} 22.2$ & Não \\
SMN1 & $5 \mathrm{q} 12.2-5 \mathrm{q} 13.3$ & Não \\
$S M N 2$ & $5 \mathrm{q} 12.2-5 \mathrm{q} 13.3$ & Não \\
$P O N$ & $7 \mathrm{q} 21.3$ & Não \\
$P R P H$ & $12 \mathrm{q} 13.12$ & Não \\
$V E G F$ & $6 \mathrm{p} 21$ & Não \\
$P G R N$ & $17 \mathrm{q} 21.31$ & Não \\
SOD1 & $21 \mathrm{q} 22.1$ & Sim \\
$F U S$ & $16 \mathrm{q} 11.2$ & Sim \\
$T A R D B P$ & $1 \mathrm{p} 36.22$ & Sim \\
$C 9 O R F 42$ & $9 \mathrm{p} 21.2$ & Sim \\
$A T X N 2$ & $2 \mathrm{q} 33.2$ & Sim \\
$C H M P 2 B$ & $18 \mathrm{q} 21$ & Sim \\
NFH & $22 \mathrm{q} 12.2$ & Sim \\
\hline
\end{tabular}

Nos casos familiais há um padrão mendeliano de herança, sendo majoritariamente autossômicos dominantes (ROBBERECHT \& PhILIPS, 2013). Até o momento, os genes já associados em ELAf perfazem cerca de dois terços dos casos familiais, sendo o um terço restante de etiologia ainda desconhecida (RENTON et al., 2014). Os genes associados à ELAf estão apresentados na Tabela $\mathbf{0 3 .}$

Os genes responsáveis pela maioria dos casos de ELAf descritos até o momento são SOD1, FUS, TARDBP e C9ORF72, com aproximadamente 20\%, 5\%, 5\% e 50\%, respectivamente (ROBBERECHT \& PHILIPS, 2013).

A primeira associação entre um gene específico e ELA foi feita por ROSEN et al. (1993). O gene em questão, SOD1, codifica a enzima Cu/Zn-Superóxido Dismutase, que é responsável pela dismutação do radical ânion superóxido em peróxido de hidrogênio e oxigênio molecular (CUDKOWICZ et al., 2004). Até o momento, mais de 180 variações alélicas foram descritas no gene $S O D 1$, sendo a maioria mutações missense, mas havendo também algumas deleções ou inserções (ANDERSEN \& AL-CHALABI, 2011). De maneira geral, a mutação D90A é a mais comum, porém diferenças regionais são observadas: na América do Norte a mutação A4V é a mais comum, no Reino Unido a mutação I113T, e no Japão a mutação H46R (Li \& WU, 2016). 
Tabela 03. Genes associados a ELA familial

\begin{tabular}{cccccc}
\hline Tipo & Locus & Gene & Herança & Associação com DFT \\
ELA 1 & $21 \mathrm{q} 22.1$ & SOD1 & $\mathrm{AD} / \mathrm{AR} /$ de novo & Rara \\
ELA 2 & $2 \mathrm{q} 33.2$ & $A L S 2$ & $\mathrm{AR}$ & Ausente \\
ELA 3 & $18 \mathrm{q} 21$ & Desconhecido & $\mathrm{AD}$ & Desconhecido \\
ELA 4 & $9 \mathrm{q} 34$ & SETX & $\mathrm{AD}$ & Ausente \\
ELA 5 & $15 \mathrm{q} 21.1$ & SPG11 & $\mathrm{AR}$ & Rara \\
ELA 6 & $16 \mathrm{q} 11.2$ & $F U S$ & $\mathrm{AD} / \mathrm{AR} /$ de novo & Rara \\
ELA 7 & $20 \mathrm{p} 13$ & Desconhecido & $\mathrm{AD}$ & Desconhecido \\
ELA 8 & $20 \mathrm{q} 13.3$ & VABP & $\mathrm{AD}$ & Ausente \\
ELA 9 & $14 \mathrm{q} 11.2$ & $A N G$ & $\mathrm{AD}$ & Presente \\
ELA 10 & $1 \mathrm{p} 36.22$ & $T A R D B P$ & $\mathrm{AD} / \mathrm{AR}$ & Presente \\
ELA 11 & $6 \mathrm{q} 21$ & $F I G 4$ & $\mathrm{AD}$ & Ausente \\
ELA 12 & $10 \mathrm{p} 13$ & OPTN & $\mathrm{AD} / \mathrm{AR}$ & Presente \\
ELA 13 & $12 \mathrm{q} 24$ & $A T X N 2$ & $\mathrm{AD}$ & Ausente \\
ELA 14 & $9 \mathrm{p} 13$ & $V C P$ & $\mathrm{AD}$ & Presente \\
ELA 15 & Xp11.21 & UBQLN2 & $\mathrm{XD}$ & Presente \\
ELA 16 & $9 \mathrm{p} 13.3$ & $S I G M A R 1$ & $\mathrm{AD}$ & Rara \\
ELA 17 & $3 \mathrm{p} 12.1$ & $C H M P 2 B$ & $\mathrm{AD}$ & Presente \\
ELA 18 & $17 \mathrm{p} 13.2$ & $P F N 1$ & $\mathrm{AD}$ & Ausente \\
ELA 19 & $2 \mathrm{q} 33.3-\mathrm{q} 34$ & $E R B B 4$ & $\mathrm{AD}$ & Ausente \\
ELA 20 & $12 \mathrm{q} 13.1$ & $h n R N P A 1$ & $\mathrm{AD}$ & Presente \\
ELA 21 & $5 \mathrm{q} 31.3$ & $M A T R 3$ & $\mathrm{AD}$ & Presente \\
ELA-DFT & $9 \mathrm{p} 21.2$ & $C 9 O R F 72$ & $\mathrm{AD}$ & Presente \\
ELA & $12 \mathrm{q} 24$ & $D A O$ & $\mathrm{AD}$ & Ausente \\
ELA & $2 \mathrm{p} 13$ & $D C T N 1$ & $\mathrm{AD}$ & Ausente \\
ELA & $22 \mathrm{q} 12.2$ & $N F H$ & $\mathrm{AD}$ & Ausente \\
\hline
\end{tabular}

*AD: Autossômica Dominante; AR: Autossômica Recessiva; XD: ligada ao cromossomo X

Mais de 60 mutações no gene FUS (fused in sarcoma) foram relacionadas à ELA, sendo R521C a mais comum (ANDERSEN \& AL-CHALABI, 2011). A proteína FUS está envolvida na transcrição e splicing de RNA e apresenta alta homologia com a proteína TDP43. Esta última, codificada pelo gene $T A R D B P$, também está relacionada com o metabolismo de RNA e possui mais de 50 mutações associadas com ELA (LI \& WU, 2016), sendo comum a associação com DFT.

Atualmente, a maior parte dos casos de ELAf está associada a expansões massivas do hexanucleotídeo GGGGCC (G4C2) na região não codificante C9ORF72, atingindo cerca de um terço dos casos de ELAf na América do Norte e Europa (SMITH et al., 2013). Esta 
alteração está associada com ELA, ELA-FTD e outras DNMs, como AMP e ELP (BoYLAN, 2015), e ainda com outras doenças neurodegenerativas, como o Alzheimer (MAJOUNIE et al., 2012), Huntington (Hensman et al., 2014) e Parkinson (LESAGE et al., 2013).

As proteínas codificadas por estes genes atuam em diferentes vias moleculares. A via exata que causa a degeneração em ELA permanece desconhecida, mas, como ocorre em outras doenças neurodegenerativas, é provável que haja uma interação complexa entre vários mecanismos patogênicos não mutuamente exclusivos (MANCUSO \& NAVARRO, 2015).

\subsection{Mecanismos moleculares alterados em ELA}

Os genes associados à ELA estão agrupados na Figura 01 segundo os mecanismos moleculares que estão alterados. Os principais mecanismos descritos até o momento são: estresse oxidativo (BARBER \& SHAw, 2010; CoPPEDÈ, 2011; CAI et al., 2005; Yen et al., 2004; D’Amico et al., 2013), processamento de RNA (CHEN et al., 2004; CALINI et al., 2013; VANCE et al., 2009; JOHNSON et al., 2014; GREENWAY et al., 2006; KABASHI et al., 2008; WALSH et al., 2015), excitotoxicidade (Mitchell et al., 2010), tráfego e sinalização intracelular (KUIJPERS et al., 2013; VILARIÑO-GÜELl et al., 2009; BELZIL et al., 2013; CHOW et al., 2009; RENTON et al., 2012; MARUYAMA et al., 2010; LAI et al., 2009; CoX et al., 2010; Al-Chalabi et al., 1999), proteostase e agregação proteica (BARBER \& SHAW, 2010; MARUYAMA et al., 2010; DENG et al., 2011; JOHNSON et al., 2010; CHOW et al., 2009; PARKINSON et al., 2006) e disfunção mitocondrial (MUYDERMAN \& CHEN, 2014).

O estresse oxidativo pode levar a danos estruturais e afetar a sinalização redox nas células por meio do acúmulo de espécies reativas de oxigênio e nitrogênio (EROs e ERNs, respectivamente). Este mecanismo em células de vida longa, como os neurônios, pode ter papel preponderante na morte celular (ROSEN et al., 1993). Proteínas associadas ao metabolismo redox na célula, como SOD1, mostram a importância do estudo das vias redox para o entendimento da patofisiologia de ELA.

O processamento de RNA foi implicado pela primeira vez em degeneração de neurônios motores pela identificação de mutações em SMN1 como causa de AME (LEFEBRVE et al., 1995). Porém, foi a associação das ribonucleoproteínas TDP-43 e FUS à ELA que elevou a importância do processamento de RNA na patofisiologia da doença (VANCE et al., 2009; KABASHI et al., 2008). Ambas possuem dois domínios de reconhecimento de RNA que, quando mutados, podem afetar o transportes de mRNAs ao longo do axônio, causando, assim, danos ao neurônio. Alternativamente, a diminuição da expressão nuclear de proteínas 
poderia interromper vários aspectos do processamento de RNAs, como o splicing de prémRNAs, a exportação de mRNAs nucleares, o endereçamento de mRNAs para diferentes compartimentos citoplasmáticos e o processamento de RNAs não codificantes (FERRAIUOLO et al., 2011).

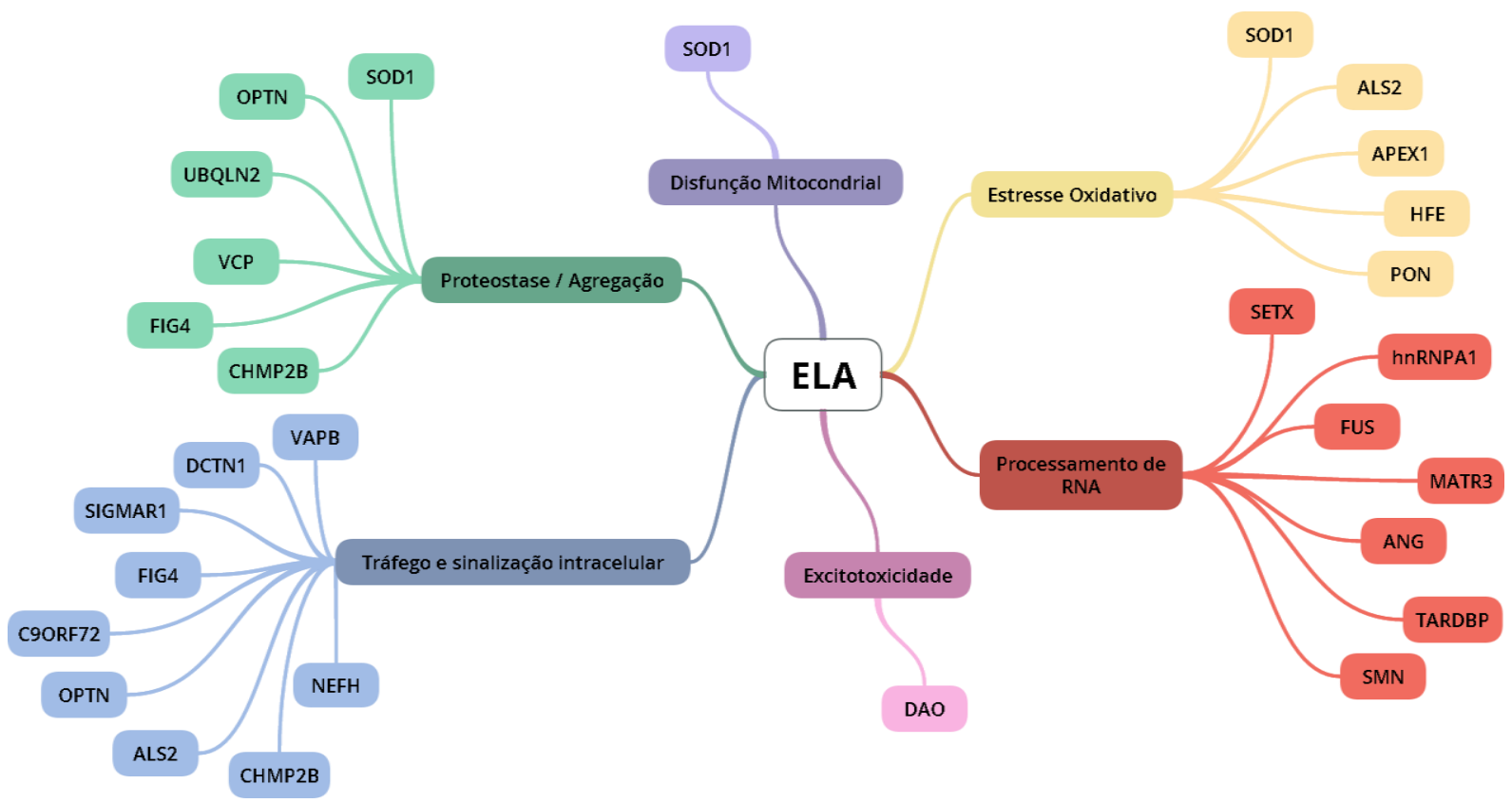

Figura 01. Mecanismos moleculares associados à patofisiologia de ELA (adaptado de COATTI et al., 2015).

A excitoxicidade é causada pela ativação excessiva dos receptores de glutamato, seja pelo aumento dos níveis sinápticos de glutamato, seja pelo aumento da sensibilidade do neurônio pós-sináptico ao glutamato. Este mecanismo altera a homeostase neuronal e pode provocar lesões do neurônio motor (VAN DAMME et al., 2005). A enzima DAO (daminoácido oxidase), responsável pela desaminação oxidativa de d-aminoácidos, como dserina, é ativadora e co-agonista de NMDA (N-metil d-aspartato) e mutações no gene que codifica DAO estão associadas à ELA (MITCHELL et al., 2010).

Alterações no tráfego intracelular têm sido associadas a vários subtipos genéticos de ELA, como aqueles causados pelas mutações nos genes FIG4, C9ORF72, entre outros. A proteína FIG4, uma fosfatase, controla a abundância celular de fosfatidilinositol 3,5bifosfato, um lipídeo sinalizador que atua no tráfego retrógrado de vesículas endossomais para o aparelho de Golgi. Mutações em FIG4 são particularmente suscetíveis a estas alterações, uma vez que são dependentes do turnover de componentes de membrana (Michell \& Dove, 2009). FARG et al. (2014) mostraram que em pacientes com expansões na 
C9ORF72 o tráfego intracelular dependente de proteínas Rab está alterado.

A agregação proteica na forma de inclusões ubiquitinadas é uma característica central em ELA. Várias proteínas, como SOD1, FUS, TDP-43, VCP, entre outras, formam agregados em pacientes com ELAf e modelos animais (FERRAIUOLO et al., 2011).

Evidências de disfunção mitocondrial em ELA foram observadas em modelos murinos de SOD1 nos quais esta proteína formava agregados no espaço intermembrana, afetando a importação de proteínas pela membrana mitocondrial externa (VANDE VELDE $e t$ al., 2008). Além disso, alterações na morfologia mitocondrial foram observadas em músculo estriado esquelético e neurônios motores de pacientes de ELAe (SASAKI \& IWATA, 2007).

As causas que levam à morte seletiva dos neurônios motores em ELA são ainda desconhecidas. O tamanho extenso dos prolongamentos dos neurônios motores pode ser um fator relevante, pois mecanismos de tráfego, sinalização, metabolismo energético e regulação da distribuição do RNA mensageiro para a síntese proteica poderiam ser mais afetados por esta característica intrínseca (FERRAIUOLO et al., 2011). Além disso, a maior demanda energética nestas células pode favorecer alterações mitocondriais que aumentam o estresse oxidativo e os níveis de cálcio extracelular (SUlLIVAN et al., 2004; PANOV et al., 2011).

\section{METABOLISMO REDOX}

\subsection{Radicais livres, estresse oxidativo e defesas antioxidantes}

Radicais livres são moléculas ou átomos que possuem um ou mais elétrons desemparelhados, alguns dos quais apresentam propriedade oxidativa (HALLIWELL \& GUTTERIDGE, 2006).

As espécies reativas, outro termo bastante usado na área redox, incluem as espécies radicalares livres e outras que, embora não possuam elétrons desemparelhados, são muito reativas em decorrência de sua instabilidade (RIBEIRO et al., 2005).

As espécies radicalares mais comuns são o radical ânion superóxido $\left(\mathrm{O}_{2}{ }^{\circ}\right)$, o radical hidroxila $\left(\mathrm{OH}^{*}\right)$ e o radical óxido nítrico $\left(\mathrm{NO}^{\circ}\right)$. As espécies não radicalares mais comuns incluem o peróxido de hidrogênio $\left(\mathrm{H}_{2} \mathrm{O}_{2}\right)$, os hidroperóxidos orgânicos $(\mathrm{ROOH})$, o oxigênio singlete $\left({ }^{1} \mathrm{O}_{2}\right)$ e o peroxinitrito $\left(\mathrm{ONOO}^{-}\right)$(HALLIWELL \& GUTTERIDGE, 2006).

Historicamente, o termo estresse oxidativo se refere ao desequilíbrio entre a produção de espécies reativas de oxigênio/nitrogênio (EROs/ERNs) e a remoção destas espécies e reparo dos danos causados por elas (HALLIWELl \& GUTTERIDGE, 2006). JONES (2006), 
alternativamente, define estresse oxidativo como uma perturbação no controle e na sinalização redox. Esta definição parece mais útil para relacionar processos redox com doenças que representariam um estado patológico menos drástico do que a morte celular.

As espécies reativas reagem com um grande número de moléculas diferentes e podem desencadear a morte celular por diversas vias diferentes ao provocar danos às biomoléculas. Lipídios insaturados são particularmente suscetíveis a danos oxidativos e a peroxidação lipídica, constituindo importantes marcadores de estresse oxidativo. As quatro bases nitrogenadas do DNA também são suscetíveis a danos oxidativos e produtos como a 8hidroxiguanina e 8-hidroxi-2-desoxiguanina atuam como marcadores de estresse oxidativo. Para proteínas, eventos de carbonilação e nitrotirosinação são importantes e geram produtos específicos detectáveis (BARNHAM et al., 2004).

As EROs são produzidas por uma série de vias diferentes. As principais fontes endógenas são a degradação de ácidos graxos nos peroxissomos, os mecanismos de detoxificação pelo citocromo P-450, o processo de fagocitose e, principalmente, a cadeia transportadora de elétrons. Durante a respiração mitocondrial, a cadeia transportadora de elétrons cria um fluxo de elétrons através da cadeia respiratória. Este fluxo estabelece um gradiente de prótons, através da membrana mitocondrial interna, que é usado como uma fonte de energia para a síntese de ATP. Os elétrons são extraídos a partir de substratos reduzidos e são transferidos para o oxigênio molecular $\left(\mathrm{O}_{2}\right)$ através de uma cadeia de complexos enzimáticos (I a IV). No passo final da cadeia transportadora de elétrons, citocromo c oxidase (complexo IV) garante a redução completa de $\mathrm{O}_{2}$ à água sem a formação de radicais de oxigênio. No entanto, pode ocorrer a redução parcial de $\mathrm{O}_{2}$ e a geração do radical ânion superóxido $\left(\mathrm{O}_{2}{ }^{-}\right)$(BALABAN et al., 2005). Estima-se que $0,1 \%$ a $0,5 \%$ do oxigênio consumido na mitocôndria são apenas parcialmente reduzidos formando, em consequência, $\mathrm{O}_{2}{ }^{--}$(BAYNE et al., 2005). Este radical pode ser subsequentemente dismutado a $\mathrm{H}_{2} \mathrm{O}_{2}$ e $\mathrm{O}_{2}$ pela enzima $\mathrm{Cu} / \mathrm{Zn}-\mathrm{SOD} 1$ no espaço intermembrana ou pela enzima Mn-SOD2 na matriz mitocondrial. Sendo assim, grande parte do $\mathrm{H}_{2} \mathrm{O}_{2}$ produzido intracelularmente é subproduto da respiração celular.

As células podem se defender contra os danos provocados por EROs por meio da utilização de mecanismos específicos que podem ser enzimáticos ou não-enzimáticos (BonNEFOY et al., 2002). Dentre as enzimas que atuam no metabolismo redox temos a SOD, a glutationa peroxidase (GPx), a catalase, as peroxirredoxinas (Prxs), entre outras.

Os antioxidantes não-enzimáticos incluem o ácido ascórbico (vitamina C), o tocoferol (vitamina E), a glutationa, a N-acetil-L-cisteína, entre outros (BORELLA \& VARELA, 2004). 
Estas moléculas atuam prioritariamente como agentes quelantes de metais, como bloqueadores de peroxidação ou componentes de ciclos de óxido-redução (GILGUN-SHERKI et al., 2001).

A glutationa é o tiol celular mais abundante e é um dos principais agentes protetores contra a ação de EROs e ERNs. Ela atua por meio da redução destas espécies de forma nãoenzimática ou por ação conjunta com a enzima glutationa peroxidase. Com a redução das espécies reativas, há a formação de glutationa dissulfeto, GSSG, que, por sua vez, pode ser reduzida a GSH pela ação da enzima glutationa redutase (GR) com elétrons provenientes de NADPH (DiCKINSON \& FORMAN, 2002). Além disso, a conjugação de GSH com compostos eletrofílicos, mediada pela glutationa-S-transferase (GST), e subsequente eliminação destes conjugados, também protegem as células de subprodutos tóxicos do metabolismo (DRINGEN, 2000). Quando o estado redox de uma célula é alterado, ocorre um aumento na demanda de GSH e maior formação de GSSG. O esgotamento de GSH resultante deste processo é atenuado pela síntese de novo desta molécula. Assim, os níveis de GSH e GSSG celular comumente vêm sendo usados como indicadores do estado redox na célula (GRIFFITH, 1999). É necessário, porém, ter em conta que a razão GSH/GSSG e outros sistemas tiol/dissulfeto, como a razão tiorredoxina reduzida/tiorredoxina oxidada (-SH2/-SS-) e a razão cisteína/cistina (Cys/CySS), não estão sempre em equilíbrio redox e podem, portanto, funcionar como pontos-chave de sinalização em processos redox-dependentes (JONES, 2006; HANSEN et al., 2006).

A N-acetil-L-cisteína (NAC) é um aminoácido que atua como antioxidante diretamente, substituindo o papel de redutor que a glutationa possui, ou indiretamente, por ser um de seus precursores ao disponibilizar resíduos de cisteína. O seu uso têm sido avaliado como potencial agente na atenuação do estresse oxidativo em diferentes enfermidades (LI et al., 2016; NAZIROĞLU et al., 2014; UNNITHAN et al., 2014; JiANG et al., 2013).

\subsection{O estresse oxidativo em ELA}

Diversos estudos evidenciam o estresse oxidativo como um dos possíveis mecanismos envolvidos na morte de neurônios motores em ELA. Marcadores de estresse oxidativo têm sido repetidamente encontrados em pacientes de ELAe, o que indica relevância para a questão (D'AMICo et al., 2013).

O interesse nos mecanismos de estresse oxidativo em ELAf surgem a partir da associação de ELA1 com a enzima Cu/Zn-SOD1, uma vez que esta enzima possui um papel 
importante como defesa antioxidante. Foi inicialmente sugerido que as mutações em SOD1 levariam ao fenótipo por (1) uma perda de função da proteína, o que levaria ao aumento dos níveis de $\mathrm{O}_{2}{ }^{\circ}$, que, por sua vez, ao reagir com outras moléculas poderia produzir espécies ainda mais reativas; (2) por um mecanismo dominante-negativo em que a proteína mutante SOD1 é não só inativa, mas também inibe a função da proteína selvagem; ou (3) pelo aumento da atividade de SOD1, que levaria a maior produção de $\mathrm{H}_{2} \mathrm{O}_{2}$ e $\mathrm{OH}^{*}$. (BARBER et al., 2006). Hoje, porém, a hipótese de um ganho de função tóxica associada a um efeito dominante negativo parece ser mais aceita.

Em outros casos familiais, o estresse oxidativo tem recebido atenção e parece desempenhar um papel importante na patologia. Por exemplo, a expressão da proteína VCP mutante (ELA14) em células de neuroblastoma humano SH-SY5Y as torna sensíveis ao estresse oxidativo induzido por tratamento com L-butionina sulfoximina, um inibidor da síntese de glutationa (HIRANO et al., 2014).

A expressão de TDP-43 mutante (ELA10) leva a um aumento nos marcadores de estresse oxidativo, apoptose e necrose em levedura (BRAUN et al., 2011) e ao aumento de carbonilação de proteínas e dos níveis de glutationa-S-transferase em Drosophila melanogaster (ZHAN et al., 2015).

Em pacientes com ELA1, ELA6 e ELA 10 a proteína PDI1 colocaliza com SOD1, FUS e TDP-43, respectivamente, sendo esta proteína um marcador de estresse do retículo, UPR e estresse oxidativo, uma vez que está envolvida no enovelamento proteico (ATKIN et al., 2008; HonJo et al., 2011; FARG et al., 2012; WALKER et al., 2013). Além disso, PDI colocaliza com inclusões formadas por VAPB (ELA8) em um modelo de Drosophila (TsUDA et al., 2008).

\section{Proteostase Celular}

A proteostase celular é mantida por um sistema complexo de vias e mecanismos que coordenam síntese, enovelamento, desagregação e degradação de proteínas (POWERS et al., 2009).

Grande parte das proteínas sintetizadas por uma célula eucariótica ocorre em ribossomos aderidos à membrana do RE. O correto enovelamento de proteínas no RE é monitorado por mecanismos de controle de qualidade de proteínas do RE, denominados coletivamente como ERQC (ER Quality Control). As proteínas que passam pelos critérios de transporte do ERQC são destinadas para as vias secretórias, mas quando a funcionalidade de 
uma proteína mal-enovelada ou em agregação não pode ser restaurada, aumentando a sua propensão para formar grandes agregados, diversas chaperonas ajudam a direcionar essa proteína para vias de degradação. Se, ainda assim a concentração dessas proteínas potencialmente tóxicas à célula aumenta, vias compensatórias são induzidas (VEMBAR \& BRODSKY, 2008). Uma dessas vias é a UPR (Unfolded protein response) (SCHRÖDER, 2008), que envolve a ativação transcricional de vários genes, sendo evolutivamente conservada desde leveduras até mamíferos (MORI, 2009). Os dois principais mecanismos de degradação são o sistema ubiquitina-proteassomo (UPS) e a autofagia (LABBADIA \& MORIMOTO, 2015). Os principais mecanismos estão resumidos na Figura 02.

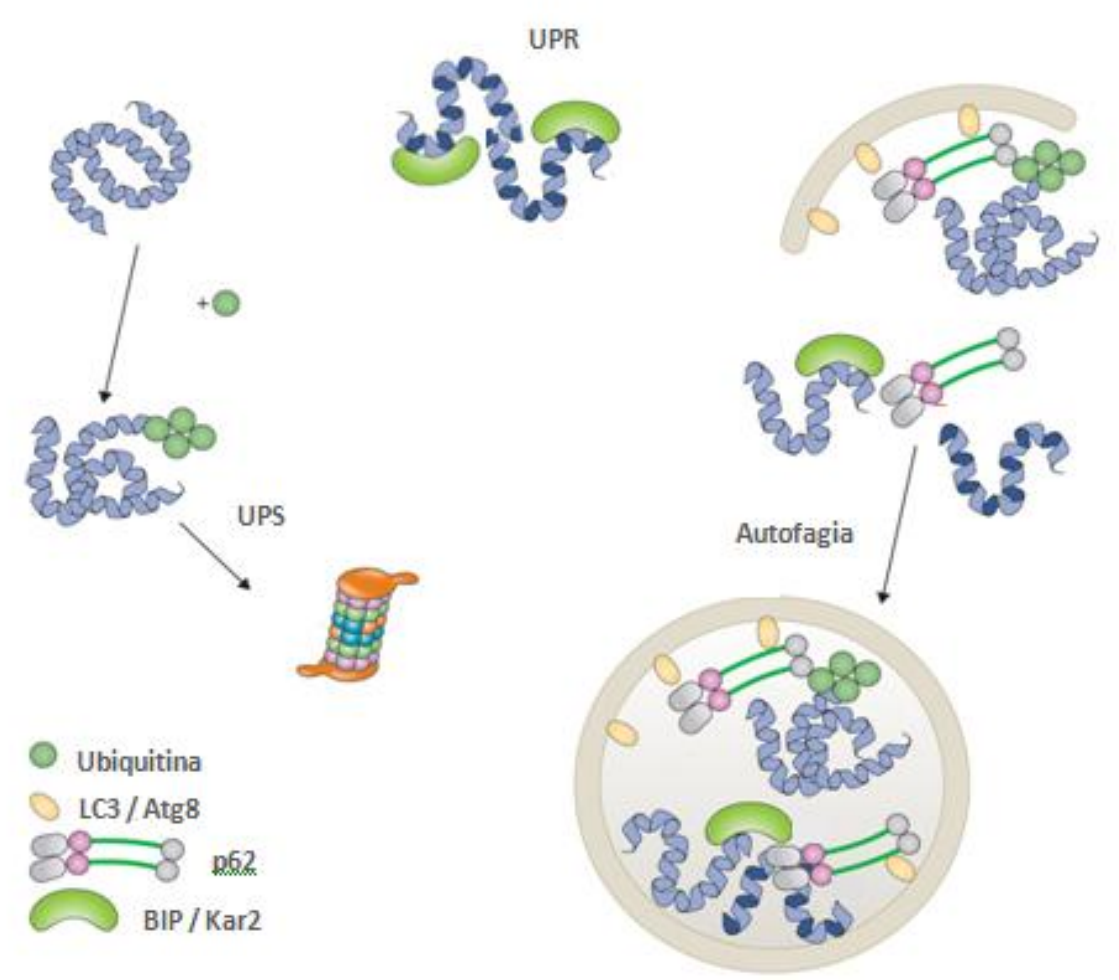

Figura 02. Proteostase em eucariotos (adaptado de MARTENS \& BACHMAIR, 2015). O proteassomo degrada proteínas individualmente e a via canônica depende de marcação específica com o peptídeo ubiquitina. A autofagia é capaz de degradar agregados e proteínas que não podem ser degradadas pelo proteassomo. A UPR associa ambos os mecanismos e regula vias de apoptose.

\subsection{O sistema ubiquitina-proteassomo (UPS)}

A degradação via UPS depende de marcação específica com ubiquitina, um polipeptídeo de 76 aminoácidos altamente conservado. A ligação covalente da ubiquitina com o substrato a ser degradado ocorre através de um mecanismo em cascata de três passos. Primeiramente a ubiquitina é ligada a um resíduo de cisteína de uma enzima E1 ativadora de 
ubiquitna em uma reação dependente de ATP. Após esta ligação, a ubiquitina ativada é transferida para uma enzima E2 conjugadora de ubiquitina. Finalmente, a ubiquitina é ligada por um resíduo de lisina à proteína a ser marcada direta ou indiretamente por uma enzima E3 ligase de ubiquitina. A ubiquitina pode se ligar ao substrato de várias maneiras, gerando um amplo repertório de sinais com diferentes topologias e comprimentos que podem ser encaminhados para vias diversas. A marcação para degradação via proteassomo é composta por, pelo menos, quatro ubiquitinas ligadas entre si através do resíduo de lisina (K48) (CHAU et al., 1989).

O proteassomo é uma protease complexa formada por duas subunidades distintas que possuem componentes e funções diferentes. A subunidade 19S tem função regulatória e reconhece substratos ubiquitinados, remove suas cadeias de ubiquitina, promove o seu desdobramento e o encaminha para a degradação na subunidade catalítica, o 20S (FINLEY, 2009).

Apesar de possuir localização citosólica e nuclear, o proteassomo está associado ao ERAD ("Endoplasmic-reticulum-associated protein degradation"), um mecanismo de degradação associado ao RE. As proteínas mal-enoveladas formadas no RE são reconhecidas por um dos dois complexos do ERAD, Doa10 ou Hrd1, translocadas para o citoplasma, ubiquitinadas pela E3 ligase correspondente e encaminhadas para o proteassomo (Figura 03) (NAKATSUKASA et al., 2014).

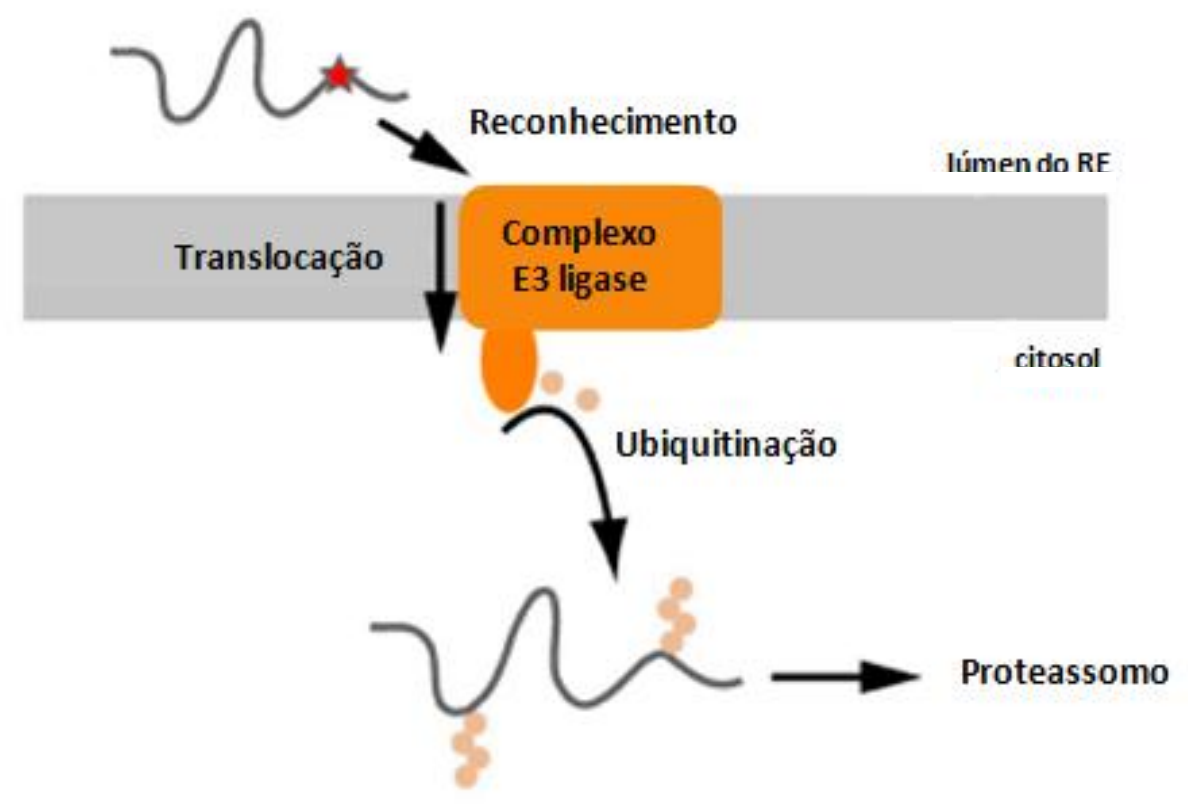

Figura 03. O ERAD (adaptado de RUGGIANO et al., 2014).

\subsection{A autofagia}


Embora o proteassomo seja o mecanismo mais comum de degradação de proteínas no citosol da célula, limitações biofísicas da subunidade $20 \mathrm{~S}$ do proteassomo não permitem a degradação de grandes complexos de proteínas mal-enoveladas (FINLEY, 2009). Alternativamente, esses substratos são direcionados para o lisossomo, que contém uma série de proteases não específicas que podem degradar uma ampla gama de substratos (YANG \& KLIONSKY, 2010). Este processo, denominado autofagia, possui três formas distintas: a microautofagia, a macroautofagia e a autofagia mediada por chaperonas, este última descrita apenas em mamíferos (LABBAdiA \& MoRimoto, 2015). A Figura 04 sumariza os tipos de autofagia presentes em leveduras.

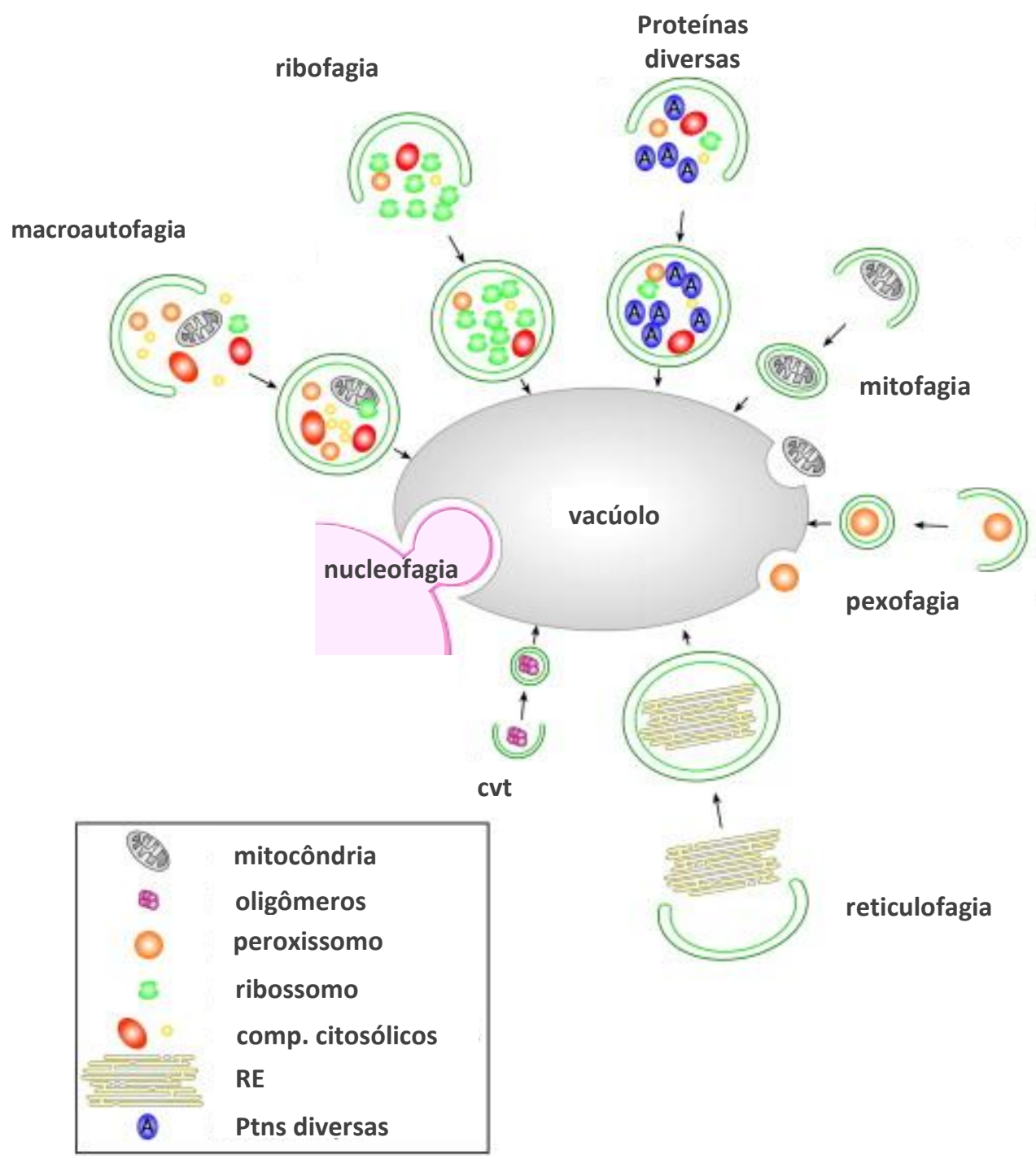

Figura 04. Os diferentes tipos de autofagia em S. cerevisiae (adaptado de KRAFT et al., 2009). 
A microautofagia ocorre quando há necessidade do turnover de mitocôndrias (DEFFIEU et al., 2009), de partes do núcleo (KRICK et al., 2008), de peroxissomos (DUNN et al., 2005), do RE (CEBOLLERO et al., 2012) e outras organelas. O componente a ser eliminado

é recrutado e sequestrado diretamente pelas membranas vacuolares e, por invaginação, entregue ao lúmen vacuolar, onde será degradado.

A macroautofagia é a forma mais bem estudada de autofagia e implica o sequestro de organelas ou regiões do citoplasma em uma estrutura vesicular de membrana dupla, o autofagossomo. Este autofagossomo é, então, transportado para o vacúolo onde, após fusão com este, disponibiliza o substrato para a degradação (YANG \& KLIONSKY, 2010).

A autofagia é um processo dinâmico que depende de um número grande de proteínas e possui regulação ainda pouco conhecida. Um dos componentes mais importantes no processo autofágico é Atg8. Esta proteína é uma ubiquitin-like protein que sofre ação proteolítica da protease Atg4. A partir desta ação, ocorre a exposição de um resíduo de glicina que pode se ligar covalentemente à fosfatidiletanolamina, formando o complexo Atg8-PE. Este é, então, incluído nas membranas do autofagossomo em formação (NAKATOGAWA et al., 2009). Atg8-PE forma uma capa na superfície dos autofagossomos impedindo a fusão prematura destes com o vacúolo. Atg8-PE é removido em um evento que antecede a fusão do autofagossomo com o vacúolo por meio de uma segunda clivagem mediada por Atg4 (KLIONSKY, 2005).

\subsection{Unfolded protein response (UPR)}

O acúmulo de proteínas mal-enoveladas no RE leva à UPR. Em situações de estresse prolongado e da inabilidade da célula em reverter este estresse, ocorre a indução de apoptose (SCHRÖDER, 2008). Diferentes condições celulares podem levar a este acúmulo de proteínas mal-enoveladas, como a grande demanda de secreção de proteínas (GASS et al., 2002; LIPSON et al., 2006), infecções virais (ISLER et al., 2005), privação de nutrientes e oxigênio (LEE, 1992; FELDMAN et al., 2005) e expressão de proteínas mutantes (BARTOSZEWSKI et al., 2008; ITO \& SUZUKI, 2009). A Figura 05 compara a UPR em levedura e em mamíferos.

Em levedura, a UPR é ativada pela via de Ire1 (OIKAWA et al., 2009). Esta proteína transmembrana é codificada pelo gene Irel e funciona como serina/treonina quinase e endoribonuclease (SIDRAUSKI \& WALTER, 1997). Quando há acúmulo de proteínas malenoveladas no RE, a chaperona Kar2, outro componente da UPR em leveduras, se dissocia de Ire1 e se liga a estas proteínas. Uma vez livre, Ire1 forma oligômeros, se autofosforila e 
ganha atividade RNAse, promovendo, então, o splicing alternativo de Hacl mRNA. Hacl codifica um fator de transcrição com um domínio zíper de leucina, Hac1p, que, por sua vez, induz a expressão de genes ativados pela UPR, como aqueles que codificam chaperonas, componentes do ERAD e fatores pró-apoptóticos (NIKAWA et al., 1996).

Em mamíferos, além de IRE1 - IRE1 $\alpha$ em mamíferos - outras duas proteínas estão envolvidas na sinalização e ativação da UPR: a PERK e a ATF6. Quando há proteínas malenoveladas no RE, as proteínas BIP (homólogo de Kar2) se dissociam de IRE1, ATF6 e PERK em um processo semelhante ao que ocorre em leveduras (SZEGEZDI et al., 2006).
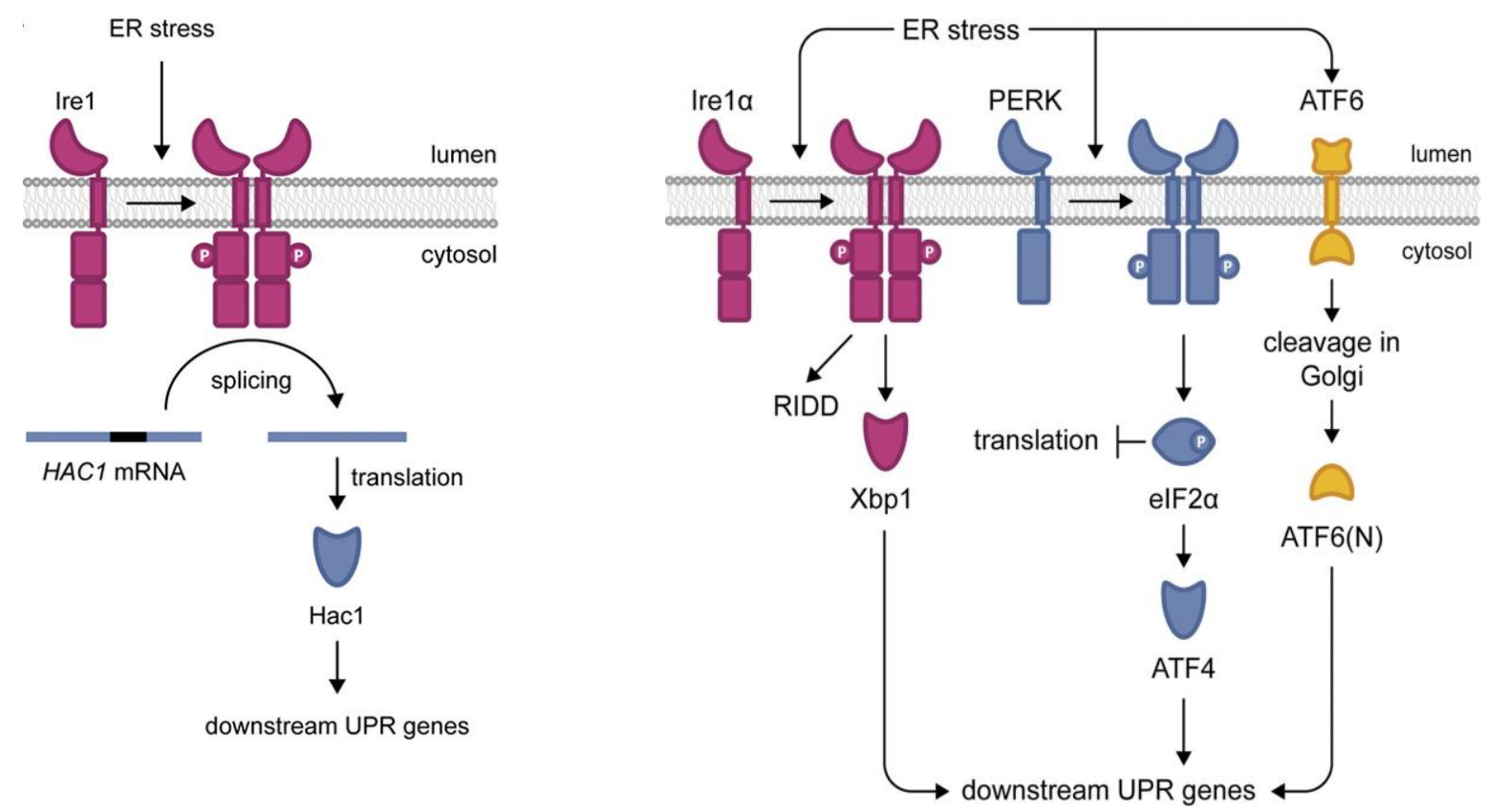

Figura 05. A UPR em leveduras e em mamíferos (adaptado de WU et al., 2014).

Com a dissociação de BIP, PERK sofre uma mudança conformacional que promove sua dimerização e autotransfosforilação (HARDING et al., 2000). Uma vez fosforilada, PERK promove a fosforilação do fator de iniciação da tradução eIF2 $\alpha$ que, por sua vez, atenua o processo de tradução global de proteínas, por impedir que eIF2B recicle o complexo eIF2, mantendo-o na forma ligada à GTP (HARDING et al., 1999). Embora a fosforilação de eIF2 $\alpha$ atenue a tradução global, ela é capaz de promover a tradução seletiva de vários mRNAs, dentre eles ATF4 (RoN, 2002). Este fator de transcrição é translocado para o núcleo e induz a expressão de genes responsivos a estresse, biossíntese e transporte de aminoácidos e apoptose (HARDING et al., 2003; MA et al., 2002).

A proteína ATF6, após dissociação de BIP, sofre uma mudança conformacional, 
seguida da translocação para o Complexo de Golgi (HAZE et al., 1999). Uma vez nessa organela, ATF6 é clivada em ATF6 $\alpha$ e ATF6 $\beta$, que são translocados para o núcleo. Estes fatores regulam a expressão de elementos responsivos ao estresse no RE como chaperonas e a transcrição de XBP1 (YosHIDA et al., 2001).

A proteína IRE1, ao se dissociar de BIP, sofre dimerização e promove o splicing alternativo de XBP1. Uma vez no núcleo, a forma processada de XBP1 controla a transcrição de chaperonas, genes envolvidos na degradação de proteínas e o inibidor de PERK, P58 ${ }^{\text {IPK }}$ (SZEGEZDI et al., 2006).

A ação conjunta destas três proteínas durante a UPR controla o estresse do RE pelo aumento da expressão de chaperonas e consequente melhora no enovelamento das proteínas e degradação de proteínas mal-enoveladas (SZEGEZDI et al., 2006).

\subsection{Formação de agregados proteicos}

Estudos recentes demonstraram que o sequestro de proteínas mal-enoveladas é uma característica fisiológica do controle de qualidade de proteínas no ambiente celular (ESCUSATORET et al, 2013). Diversos compartimentos celulares distintos concentram diferentes tipos de espécies proteicas mal-enoveladas, impedindo, assim, a interação com proteínas enoveladas corretamente. Dessa forma, mecanismos similares aos realizados por príons são evitados, mantendo, assim, a proteostase celular. A partir de estudos de doenças neurodegenerativas de início tardio e estudos com inibição do proteassomo e estresse celular, foram descritas inclusões contendo agregados proteicos insolúveis e solúveis em leveduras e mamíferos como o JUNQ, os Q-bodies, o IPOD e o agregossomo (SOTO \& EsTRADA, 2008; SONTAG et al., 2014).

Quando há o comprometimento da função do proteassomo, proteínas mal-enoveladas que seriam normalmente degradadas de um modo dependente de chaperonas e do UPS são sequestradas para um compartimento associado ao RE perinuclear chamado JUNQ (Juxta nuclear quality control). Estes agregados são solúveis e são marcados com ubiquitina e sua formação depende de actina (KAGANOVICH et al., 2008; SPECHT et al., 2011; MALINOVSKA et al., 2012).

Os Q-bodies, outro compartimento celular observado em eucariotos, é formado por proteínas mal-enoveladas solúveis e independe de actina e da falha do UPS. Localizados no RE cortical, os Q-bodies continuamente são formados e desfeitos, podendo, em casos de 
falha do UPS, se juntar em estruturas maiores e não degradáveis pelo proteassomo, como o JUNQ (SONTAG et al., 2014).

Além de agregados proteicos solúveis, também podem ser formados agregados de proteínas mal-enoveladas insolúveis que são sequestrados em uma estrutura denominada IPOD (Insoluble protein deposit) localizados junto ao vacúolo (KAGANOVICH et al, 2008; Tyedmers et al, 2010). Este compartimento é o principal imobilizador de proteínas do tipo amiloide e se forma independentemente da falha do UPS (SONTAG et al., 2014).

Por fim, exclusivamente em células de mamíferos, os agregados insolúveis se concentram no agregossomo, que está localizado no centrossomo (JOHNSTON et al, 1998). Os agregossomos estão associados com chaperonas e componentes do UPS e autofagia.

\subsection{Estresse do RE e estresse oxidativo}

Uma prolongada situação de estresse do RE pode ser fonte de estresse oxidativo. Durante a formação de pontes dissulfeto nas proteínas, atividade que ocorre no RE, a enzima Pdi1 (Protein disulfide isomerase 1) promove a oxidação destas, tornando-se ela mesma reduzida. A enzima Ero1 (Endoplasmic reticulum oxidoreductase 1), por sua vez, reoxida Pdi1, tornando-a novamente disponível para novo ciclo de oxidação. Ero1 reduzida transfere elétrons para o oxigênio molecular, resultando na formação de $\mathrm{H}_{2} \mathrm{O}_{2}$ (TU \& WeISSMAN, 2004). HAYNE et al. (2004) demonstraram que a expressão de Ero1 é aumentada em situações de ativação da UPR. Isto explica que, em situações de prolongado estresse do RE, haja também aumento da produção de EROs e consequente estresse oxidativo.

$\mathrm{O}$ acúmulo de proteínas mal-enoveladas no RE pode favorecer a saída de íons $\mathrm{Ca}^{2+}$ para o citosol e aumentar a produção de EROs na mitocôndria (MALHOTRA \& KAUFMAN, 2007). Esta geração de EROs induzida por $\mathrm{Ca}^{2+}$ ocorre por intermédio dos complexos proteicos da cadeia de transporte de elétrons (FEISSNER et al., 2009). Além disso, o dobramento e o redobramento de proteínas no lúmen do RE são processos altamente dependentes de energia. Assim, o acúmulo de proteínas mal-enoveladas, e a atividade UPR consequente, poderia estimular a fosforilação oxidativa mitocondrial a fim de aumentar a produção de ATP, e, assim, aumentar a produção de EROs (MALHOTRA \& KAUFMAN, 2007).

JANG et al. (2004), utilizando S. cerevisiae, demonstraram que a proteína Tsa1, uma peroxirredoxina, pode apresentar atividade chaperona em certas condições. Tsa1 possui, em condições de estresse oxidativo controlado, atividade peroxidase dependente de tióis. Porém, em situações de alto estresse oxidativo e de choque térmico, esta proteína se comporta como 
chaperona do tipo holdase ou sHSP (Small heat shock protein), formando complexos de alto peso molecular. Esta atividade chaperona também foi observada por outros grupos (KAYA et al., 2014; MACDIARMID et al., 2013; IRAQUI et al., 2009; WEIDS \& GRANT, 2014). Kimata et al. (2005) demonstraram, também em S. cerevisiae, que a expressão de Tsa1 pode ser induzida pelo uso de tunicamicina e é mediada por vias da UPR. Recentemente HAZÉn et al. (2016) mostraram que Tsa1 pode interagir fisicamente com chaperonas da família Hsp70 em um mecanismo que depende da hiperoxidação de Tsa1 por $\mathrm{H}_{2} \mathrm{O}_{2}$. Nesta situação, inclusões proteicas presentes no citoplasma induzidas por tratamento com $\mathrm{H}_{2} \mathrm{O}_{2}$ recrutam Tsa1 e as chaperonas Ssa1 e Ssa2, membros citoplasmáticos da família Hsp70. Hsp104, que atua em conjunto com as chaperonas Hsp70, é, então, recrutada por Tsa1-Hsp70 e promove a desagregação das inclusões de forma redox-dependente, com a necessidade da redução de Tsa1 pela sulforredoxina $1(\operatorname{Srx} 1)$.

\section{A FAMÍlia daS PROTEÍNAS VAP}

As proteínas VAP (VAMP-associated proteins) foram identificadas primeiramente em Aplysia californica em associações com proteínas VAMP (vesicle-associated membrane proteins) (SKEHEL et al., 1995), que são proteínas SNARE (soluble N-ethylmaleimidesensitive factor attachment protein receptor) de vesículas sinápticas (CHEN \& SCHELLER, 2001). As VAPs são proteínas de membrana do tipo II e estão ancoradas no RE, sendo conservadas em organimos eucarióticos (LEV et al., 2008).

Mamíferos possuem três proteínas da família VAP: VAPA, VAPB e VAPC. A proteína VAPA (VAMP-associated protein A), codificada pelo gene de mesmo nome localizado no cromossomo 18, possui $28 \mathrm{kDa}$ e 249 aminoácidos. As proteínas VAPB e VAPC (VAMP-associated protein B/C) são isoformas resultantes do splicing alternativo do gene $V A P B$ localizado no cromossomo 20. VAPB possui $27 \mathrm{kDa}$ e 243 aminoácidos, enquanto VAPC possui $11 \mathrm{kDa}$ e 99 aminoácidos (NISHIMURA et al., 1999).

VAPA e VAPB compartilham 63\% de identidade de sequência de aminoácidos e possuem três domínios conservados. O primeiro domínio, na porção N-terminal, é denominado MSP. Contém aproximadamente 125 aminoácidos organizados em uma estrutura globular e recebe este nome por apresentar $22 \%$ de identidade com a proteína MSP (major sperm protein) de Caenohabditis elegans. O segundo domínio, coiled-coil, é similar àqueles encontrados em outras proteínas da família VAMP. O terceiro domínio, de aproximadamente 23 aminoácidos na porção C-terminal, é transmembrana e contém o motivo 
de dimerização GxxxG (LEV et al., 2008). VAPA e VAPB podem formar homo- ou heterodímeros por meio deste domínio, porém, os homólogos de levedura, Scs2 e Scs22, não possuem o motivo e a capacidade de dimerização (RUSS \& ENGELMAN, 2000).

A proteína VAPB, objeto de estudo deste trabalho, apresenta uma sequência de 16 aminoácidos com alto grau de conservação entre as espécies no seu domínio MSP (LEV et al., 2008). Homólogos da VAPB humana foram descritos em S. cerevisiae (Scs2), C. elegans (VPR-1), D. melanogaster (VAP-33), e diversos vertebrados (PENNETTA et al., 2002).

Na Figura 06 são mostradas a estrutura da proteína VAPB e a conservação das sequências entre os homólogos de VAPB em diferentes espécies.

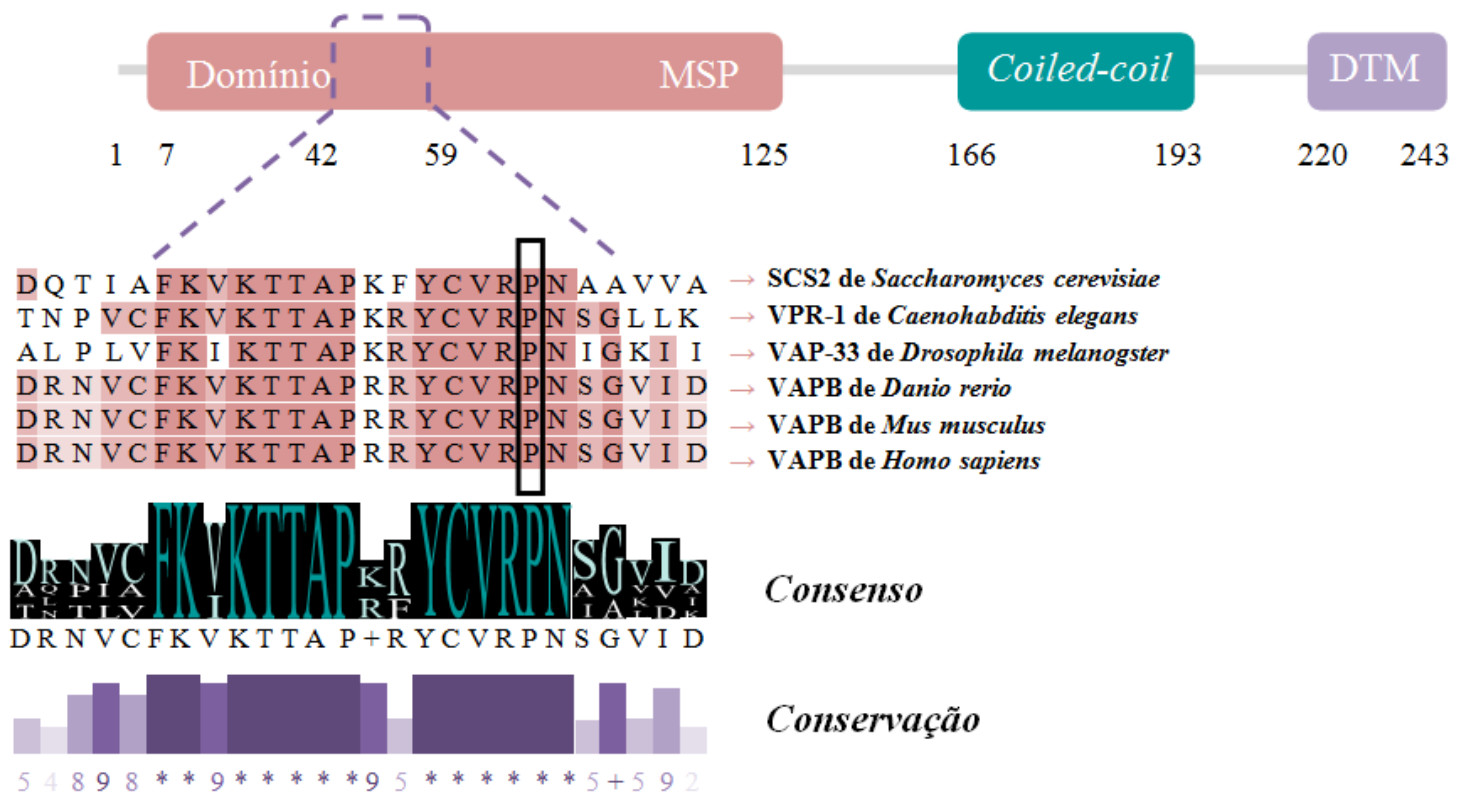

Figura 06. Estrutura e conservação da proteína VAPB (adaptado de LEV et al., 2008). O domínio MSP apresenta uma sequência de 16 aminoácidos altamente conservados entre eucariotos. A marcação evidencia a Prolina 56, mutação associada à ELA 8.

As proteínas VAP e seus homólogos parecem estar envolvidos em diferentes processos celulares, como o tráfego e sinalização intracelular, organização de microtúbulos, localização mitocondrial, homeostase de cálcio, metabolismo de lipídeos, UPR e proliferação tumoral. FOSTER et al. (2000) verificaram que a superexpressão de VAP-33 de $D$. melanogaster em mioblastos regula o transporte de GLUT4 (glucose transporter 4) para a superfície celular em resposta ao tratamento com insulina. Além disso, WEIR et al. (2001) sugerem que VAPA, pela sua interação com diferentes proteínas SNARE, atue no tráfego de vesículas entre o RE e o Aparelho de Golgi.

O domínio MSP de VAP-33 pode atuar como sinalizador ao ser clivado, secretado e 
se ligar a receptores de efrina, modulando sua atividade e competindo com as moléculas de efrina (TSUDA et al., 2008).

O papel da VAPB na estabilização de organelas pelos microtúbulos foi sugerido por AMARILIO et al. (2005). O autor observou a VAPB como um ligante entre a membrana do RE e o citoesqueleto em células HeLa e HEK293. Isso ocorreu após a superexpressão de VAPB e Nir3, uma proteína com motivos FFAT ligante de VAPB, causar uma mudança estrutural no RE, com agregação de microtúbulos ao longo de suas membranas. No trabalho de PENNETTA et al. (2002) foi observado que VAP-33 de D. melanogaster está envolvida na organização dos microtúbulos nos terminais pré-sinápticos.

Em C. elegans, VPR-1 pode ter papel preponderante na localização, morfologia, mobilidade e nos processos de fissão e fusão em mitocôndrias (HAN et al., 2012). Além disso, VAPB interage com a proteína mitocondrial PTPIP51 formando uma ligação entre RE e mitocôndria que parece ser essencial para a homeostase de $\mathrm{Ca}^{2+}$ em células HEK293 (DE Vos, 2012).

A proteína Scs2, homóloga de VAPB em levedura, interage com várias proteínas com o motivo FFAT que estão associadas ao metabolismo de lipídeos (LOEWEN et al., 2003), como a síntese e degradação de fosfatidilinositóis e fosfatidilcolina (KAGIWADA et al., 2003).

KANEKURA et al. (2006) sugerem que a superexpressão de VAPB ${ }^{\mathrm{WT}}$ promove a UPR ao interagir com IRE1, um componente fundamental da UPR. De modo similar, GKOGKAS et al. (2008) associa VAPA e VAPB à UPR por meio da interação com ATF6.

Em D. melanogaster a proteína VAP-33 parece ser necessária para o controle de qualidade de proteínas do RE (ERQC), uma vez que sua ausência leva à expansão e ao estresse do RE (MOUSTAQIM-BARRETTE et al., 2014).

RAO et al. (2012) fornecem evidências de que VAPB regula a ativação de AKT e a proliferação de células tumorais de mama. Verificou-se que a expressão da proteína VAPB é elevada em amostras tumorais metastáticas, e os níveis de expressão de mRNAs de VAPB estão negativamente correlacionados com a sobrevida de pacientes com câncer de mama.

\subsection{VAPB e ELA 8}

A primeira mutação pontual na VAPB associada à ELA foi identificada por NiSHIMURA et al. (2004) em uma família brasileira que possuía 28 indivíduos afetados distribuídos em quatro gerações. A mutação (c.C166T, p.P56S), que ocorre no domínio MSP da proteína, é herdada de forma autossômica dominante e leva a um quadro de progressão 
lenta da doença, denominado ELA 8. Trabalhos posteriores identificaram outras famílias que possuíam a mesma mutação, sugerindo haver um ancestral comum entre eles e um evento fundador que teria ocorrido 23 gerações atrás, em Portugal (NiSHIMURA et al. 2005). A mesma mutação foi encontrada em um paciente francês de ascendência japonesa (Millecamps et al., 2010) e um paciente alemão (FUnKE et al., 2010) sem possíveis ancestrais portugueses ou brasileiros, o que sugere não haver apenas um ancestral comum ou evento fundador para todos os casos descritos até o momento. A segunda mutação associada à ELA8 (c.C137T, p.T46I) foi descrita em um paciente de 73 anos no Reino Unido (CHEN et $a l ., 2010)$ e uma terceira (p.V234I) identificada em um paciente holandês de 43 anos que apresentava conjuntamente expansões na C9ORF72 (VAN BLITTERSWIJK et al., 2012).

Pouco se sabe a respeito das vias e processos celulares que estão alterados quando há expressão da proteína mutante VAPB ${ }^{\text {P56S }}$. TeULING et al. (2007) mostraram que VAPB ${ }^{\text {P56S }}$ pode formar agregados citosólicos que não colocalizam com marcadores do RE. Segundo o grupo, a proteína mutante é capaz de recrutar a proteína selvagem para estes agregados e isto poderia levar à perda de função de VAPB selvagem. Outros estudos também sugerem que o envolvimento da VAPB com ELA8 ocorreria por um mecanismo de haploinsuficiência (Mitne-NeTo et al., 2011), apontando para a limitação de disponibilidade da VAPB como um dos disparos para a degeneração neuronal. Embora esta seja uma hipótese atrativa para explicar o mecanismo de patogênese da mutante $\mathrm{VAPB}^{\mathrm{P} 56 \mathrm{~S}}$, efeitos tóxicos adicionais são possíveis.

DE Vos et al. (2012) sugerem que a proteína mutante altera a homeostase do cálcio na mitocôndria e no RE ao interagir de maneira aberrante com PTPIP51. Ademais, VAPB ${ }^{\text {P56S }}$ parece diminuir o transporte axonal anterógrado de mitocôndrias (MOROTZ et al., 2012).

Sugere-se, ainda, que a VAPB esteja envolvida em sinalização para a UPR, um importante processo de controle de qualidade de proteínas do RE (KANEKURA et al., 2006). Apesar de não se saber ao certo de que forma ocorreria esta sinalização, acredita-se que a expressão da proteína $\mathrm{VAPB}^{\mathrm{P} 56 \mathrm{~S}}$ levaria à desregulação da UPR.

\subsection{Modelos de ELA 8}

Os mecanismos exatos envolvidos na patogênese de ELA são limitantes para o desenvolvimento de uma terapia para a doença, e a construção de modelos adequados é fator crucial para o entendimento destes mecanismos. A precisão com que os modelos de ELA conseguem replicar sintomas clínicos e alterações celulares continua a ser uma questão 
central. Cada organismo tem as suas próprias vantagens e desvantagens como modelo. A escolha depende da questão que se coloca, sendo que, muitas vezes, é necessário executar experiências em paralelo em dois ou mais modelos para compreender diferentes aspectos de um mecanismo subjacente à doença (BERTHOD \& GROS-LOUIS, 2012).

Modelos animais são, provavelmente, os mais utilizados em pesquisas em ELA devido à sua facilidade de manipulação e por sua semelhança com a anatomia, genética e fisiologia humanas, o que torna a obtenção de informações in vivo particularmente atrativa. Atualmente os modelos animais existentes para ELA 8 são camundongo, D. melanogaster, $C$. elegans e Danio rerio (zebrafish). Além disso, modelos in vitro, como células HeLa, HEK293, e mais recentemente, neurônios derivados de iPSC de pacientes também estão disponíveis.

Até o momento, três grupos diferentes criaram modelos murinos para ELA 8. Os modelos de superexpressão de $\mathrm{VAPB}^{\mathrm{WT}} \mathrm{e} \mathrm{VAPB}^{\mathrm{P} 56 \mathrm{~S}}$ criados por TUDOR et al. (2010) não apresentaram nenhuma diferença fenotípica evidente na avaliação locomotora e de sobrevivência dos animais, porém foram observados agregados citoplasmáticos de TDP-43 em neurônios motores da medula espinhal de animais transgênicos expressando a proteína selvagem. KABASHI et al. (2013), avaliando camundongos nocaute para VAPB, observaram um comprometimento tardio da atividade motora dos animais, porém sem qualquer defeito nas junções neuromusculares ou qualquer denervação muscular. Por fim, ALIAGA et al. (2013), ao superexpressar VAPB $^{\text {P56S }}$ em camundongos, observaram defeitos motores nos animais, incluindo a diminuição da coordenação motora e equilíbrio, além do aumento de marcadores de estresse do RE, UPR e fatores pró-apoptóticos.

Dois diferentes modelos de Drosophila mostraram que a proteína VAPB ${ }^{\mathrm{P} 6 \mathrm{~S}}$ poderia atuar de forma dominante negativa. Em um modelo transgênico, a expressão da proteína humana mutante não é capaz de recuperar completamente o fenótipo da deleção de VAP-33, mas a expressão da proteína selvagem sim, o que sugere que a mutação leva a uma perda parcial de função (PENNETTA et al., 2002). No outro modelo, expressando a proteína de Drosophila com a mutação correspondente (VAP-33 ${ }^{\mathrm{P} 58 \mathrm{~S}}$ ), também se verificou que a mutação leva à perda de função associada à formação de agregados com a proteína selvagem, o que sugere um efeito dominante negativo (RATNAPARKHI et al., 2008).

HAN et al. (2012), usando C. elegans, mostraram que superexpressão de VPR-1 ${ }^{\text {P56S }}$ faz com que as mitocôndrias do tecido muscular possuam formato mais fino e ramificado comparadas com o controle. Além disso, a distribuição destas mitocôndrias também está alterada, semelhante ao que ocorre em animais nocautes para VPR-1. 
Usando D. rerio, KABASHI et al. (2013) mostraram que animais nocautes para VAPB exibiam defeitos na natação e que a expressão de $\mathrm{VAPB}^{\mathrm{P} 56 \mathrm{~S}}$ não foi capaz de recuperar o fenótipo dos animais nocaute, enquanto a VAPB ${ }^{\mathrm{WT}}$ conseguiu.

Finalmente, em um modelo de neurônio motor derivado iPSC de um paciente com ELA8 foi observado que os níveis de VAPB podem estar diretamente relacionados com a doença, estando reduzidos neste caso. Além disso, Mitne-Neto et al. (2011) não encontraram encontrados agregados de VAPB neste modelo, o que difere de outros trabalhos descritos anteriormente.

\section{SACCHAROMYCES CEREVISIAE COMO MODELO PARA DOENÇAS}

A levedura $S$. cerevisiae é um excelente organismo modelo para o estudo da biologia celular, bioquímica e genética de eucariotos por possuir processos celulares, vias moleculares, proteínas e genes que evolutivamente se mantiveram bem conservados (SMITH \& SNYDER, 2006).

A levedura foi o primeiro organismo eucarioto a ter seu genoma sequenciado e, como tal, tem servido como base de estudos genômicos (GOFFEAU et al., 1996). Aproximadamente $30 \%$ dos genes de levedura têm ortólogos no genoma humano e dois terços de todos os genes de levedura partilham pelo menos um domínio conservado com genes humanos (WALBERG, 2000). Além disso, a possibilidade de expressar proteínas de outros organismos com relativa facilidade e o seu curto tempo de divisão celular (1,5-3 horas) tornam a levedura um modelo bastante atrativo.

Alguns mecanismos conservados em eucariotos permitem usar S. cerevisiae como modelo para enfermidades como o câncer e doenças neurodegenerativas (Figura 07).

O uso de S. cerevisiae contribuiu consideravelmente para o entendimento da biologia do câncer. Dentre as descobertas feitas no modelo estão a identificação de substratos e mecanismos de ação de diversas caspases com papel ativo na enfermidade, como as caspases 3 e 8 , a descrição de atividades pró- ou anti-apoptóticas de proteínas da família Bcl-2 e estudos com a proteína supressora de tumor p53 (PEREIRA et al. 2011).

As doenças neurodegenerativas mais comuns, como Alzheimer, Parkinson, Huntington e ELA, estão associadas com a existência de agregados proteicos intracelulares, que se formam, muitas vezes, pelo mal-enovelamento (misfolding) resultante de uma mutação, deleção ou expansão de nucleotídeos. Os processos de misfolding, oligomerização e agregação proteica são facilmente estudados em levedura, pois há conservação do sistema de 
controle de qualidade de proteínas (KHURANA \& LINDQUIST, 2010).

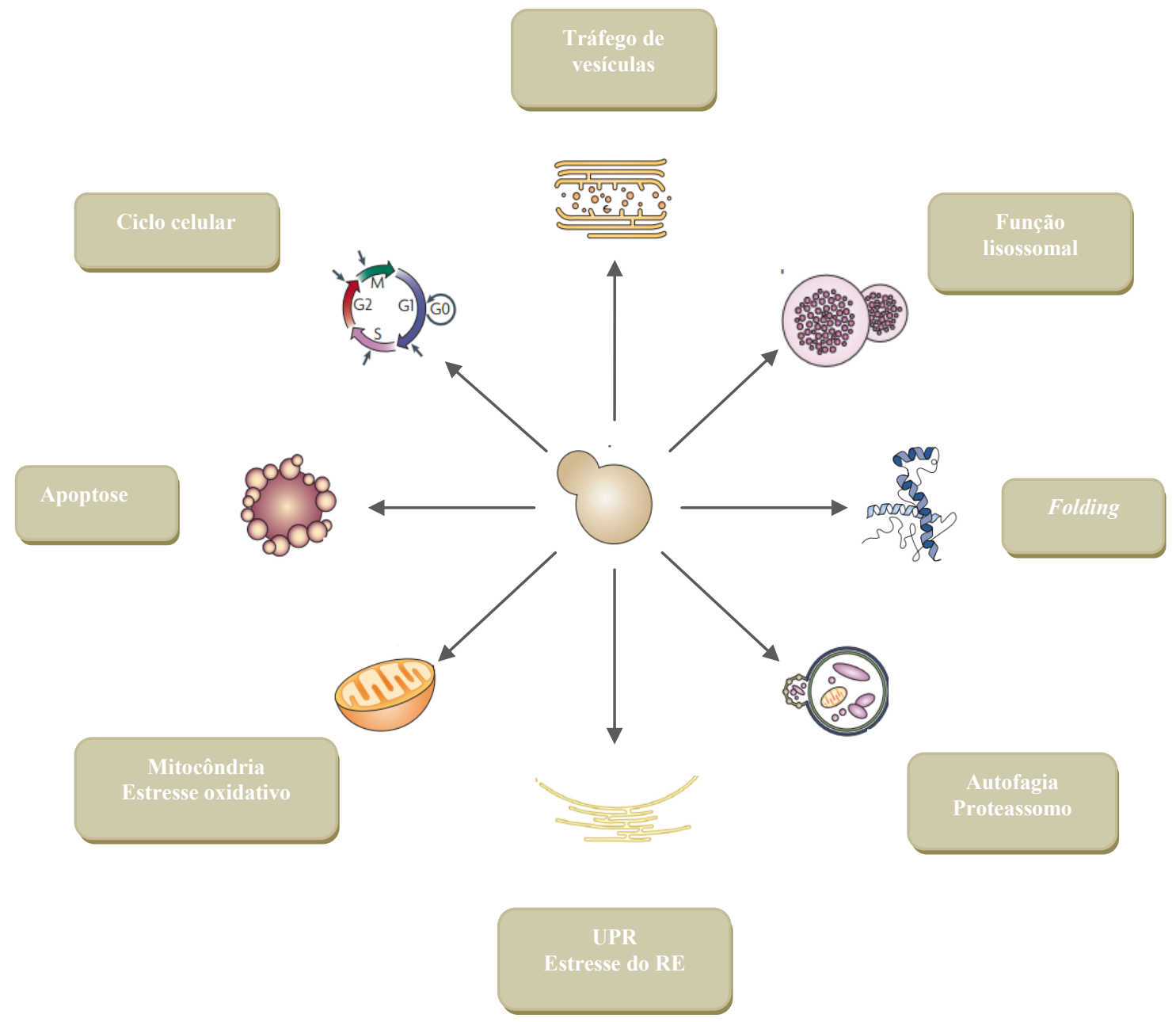

Figura 07. Mecanismos e processos celulares conservados em eucariotos (adaptado de KHURANA \& LINDQUIST, 2010).

O mecanismo de autofagia e o UPS na degradação proteica têm recebido grande atenção nas pesquisas em neurodegeneração, uma vez que são as duas principais vias de degradação proteica na célula. Estudos mostram o papel preponderante da autofagia (NAKATOGAWA et al., 2009) e do UPS (ShARMA et al., 2006) em modelos de levedura.

DUENNWALD \& LINDQUIST (2008), usando levedura como modelo de Huntington, mostraram que o estresse do RE estava aumentado em células expressando a proteína mutante. Os marcadores comumente utilizados para estresse do RE - BIP/Kar2, CHOP, ERO1 e PDI1 - são altamente conservados entre eucariotos.

O estresse oxidativo e a disfunção mitocondrial estão associados à neurodegeneração. Em levedura, tal como em mamíferos, a organela central para a produção de EROs é a 
mitocôndria. A capacidade que a levedura possui de crescer em meio fermentativo permite a análise de defeitos mitocondriais que seriam letais em células de mamífero. Desta maneira, estudos em levedura têm sido fundamentais para o entendimento da biologia mitocondrial e, eventualmente, para a descrição de alterações mitocondriais relacionadas à neurodegeneração (KNOTT et al., 2008).

Os mecanismos celulares de apoptose em levedura, apesar de menos complexos do que aqueles presentes em eucariotos superiores, apresentam sinais conservados como a condensação da cromatina, alteração do potencial de membrana mitocondrial, liberação de citocromo c, entre outros (JIN \& REED, 2002).

As funções de degradação lisossomal, tráfego de vesículas e ciclo celular possuem mecanismos e proteínas altamente conservados entre eucariotos e alguns desses mecanismos, como as vias secretoras, possuem particular interesse em neurônios.

Especificamente para ELA existem, até o momento, quatro modelos de $S$. cerevisiae: para ELA1, ELA 6, ELA 10 e ELA 13, expressando as proteínas humanas SOD1, FUS, TDP43 e ATXN2 respectivamente. Na Tabela 4 estão resumidos alguns dos avanços obtidos pela expressão da proteína humana mutante em levedura.

Tabela 04. Expressão de proteínas mutantes associadas à ELA em levedura

\begin{tabular}{|c|c|c|c|}
\hline Tipo & Proteína & Principais conclusões & Referência \\
\hline \multirow{2}{*}{ ELA 1} & \multirow{2}{*}{ SOD1 } & $\begin{array}{c}\text { Diminui a sensibilidade a hipóxia e a indutores } \\
\text { de radical ânion superóxido }\end{array}$ & $\begin{array}{l}\text { RABIZADEH et al. } \\
\text { (1995) }\end{array}$ \\
\hline & & $\begin{array}{l}\text { Diminui o fluxo de elétrons na cadeia } \\
\text { transportadora de elétrons na mitocôndria }\end{array}$ & $\begin{array}{l}\text { GUNTHER } \text { et al. } \\
\quad \text { (2004) }\end{array}$ \\
\hline \multirow{2}{*}{ ELA 6} & \multirow{2}{*}{ FUS } & $\begin{array}{l}\text { Formação de agregados tóxicos } \\
\text { citoplasmáticos }\end{array}$ & $\begin{array}{l}\text { JU et al. } \\
\text { (2011) }\end{array}$ \\
\hline & & $\begin{array}{c}\text { Agregados colocalizam com } P \text {-bodies } \\
\text { e grânulos de estresse }\end{array}$ & $\begin{array}{l}\text { SUN et al. } \\
\text { (2011) }\end{array}$ \\
\hline \multirow{3}{*}{ ELA 10} & \multirow{3}{*}{ TDP-43 } & $\begin{array}{c}\text { Formação de agregados tóxicos } \\
\text { citoplasmáticos }\end{array}$ & $\begin{array}{l}\text { JOHNSON et al. } \\
\text { (2008) }\end{array}$ \\
\hline & & $\begin{array}{l}\text { Aumento do estresse oxidativo } \\
\text { e disfunção mitocondrial }\end{array}$ & $\begin{array}{l}\text { BRAUN et al. } \\
\quad(2011)\end{array}$ \\
\hline & & $\begin{array}{l}\text { Descoberta de supressores de } \\
\text { toxicidade de TDP-43 }\end{array}$ & $\begin{array}{l}\text { ARMAKOLA et al. } \\
\text { (2012) }\end{array}$ \\
\hline ELA 13 & ATXN2 & $\begin{array}{l}\text { Deleção de } P B P 1 \text { (ortólogo de } A T X N 2 \text { em } S \text {. } \\
\text { cerevisiae) diminui a toxicidade de TDP- } 43\end{array}$ & $\begin{array}{l}\text { ELDEN } \text { et al. } \\
\quad(2010)\end{array}$ \\
\hline
\end{tabular}

Por ser um organismo unicelular, a limitação mais óbvia da levedura como modelo ocorre nas análises de aspectos histológicos, onde a multicelularidade e as interações 
celulares são importantes. Tais interações incluem as respostas imunes e inflamatórias, as transmissões sinápticas e interações glia-neuronais, entre outros. Apesar disso, a conservação de aspectos fundamentais de biologia celular ainda é um fator importante para o uso de $S$. cerevisiae na compreensão das bases moleculares de doenças e teste terapêutico, com posterior validação em sistemas mais complexos (KHURANA \& LINDQUIST, 2010). 


\section{CONCLUSÕES}

A partir dos dados obtidos conclui-se que:

1. A proteína $\mathrm{VAPB}^{\mathrm{WT}}$ no modelo de levedura é corretamente direcionada ao RE, enquanto a proteína $\mathrm{VAPB}{ }^{\mathrm{P} 56 \mathrm{~S}}$ apresenta distribuição diversa, formando agregados em diferentes frações celulares;

2. A superexpressão da proteína mutante é tóxica à levedura e diminui sua viabilidade, enquanto a expressão da proteína mutante não afeta as células;

3. A proteína $\mathrm{VAPB}^{\mathrm{WT}}$ é capaz de restaurar o fenótipo de auxotrofia ao inositol em linhagens $\Delta S c s 2$, ao contrário de $\mathrm{VAPB}^{\mathrm{P} 56 \mathrm{~S}}$;

4. A expressão da proteína mutante torna as células mais sensíveis ao tratamento com $\mathrm{H}_{2} \mathrm{O}_{2}$, agente indutor de estresse oxidativo, e apresenta alterações na razão GSH/GSSG, sugerindo haver um ambiente celular mais oxidativo. Além disso há maior produção de $\mathrm{H}_{2} \mathrm{O}_{2}$ pelas mitocôndrias. Tomados em conjunto, sugere-se que haja associação de mecanismos causadores de estresse oxidativo e a expressão de $\mathrm{VAPB}^{\mathrm{P} 56 \mathrm{~S}}$ e isto deve ocorrer de forma indireta, uma vez que $\mathrm{VAPB}^{\mathrm{P} 56 \mathrm{~S}}$ não faz parte das vias do metabolismo redox da célula;

5. O tratamento com o antioxidante NAC não é capaz de melhorar substancialmente a viabilidade das células expressando $\mathrm{VAPB}^{\mathrm{P} 56 \mathrm{~S}}$;

6. Há alterações nos marcadores de estresse do RE Pdi1 e Ero1, enzimas que participam ativamente de vias do metabolismo redox. Isto sugere que haja uma forte relação entre o estresse do RE e o estresse oxidativo neste modelo;

7. A inibição do proteassomo afeta diferencialmente a viabilidade da linhagem expressando a proteína $\mathrm{VAPB}^{\mathrm{WT}}$ e a estabilidade da proteína selvagem, sugerindo que o UPS seja o principal responsável por sua degradação;

8. A inibição da autofagia leva a um maior acúmulo de $\mathrm{VAPB}^{\mathrm{P} 56 \mathrm{~S}}$ e diminui a viabilidade das linhagens expressando esta proteína. Além disso, o uso de GFP-Atg8 revelou haver maior formação de autofagossomos nesta linhagem, sugerindo ser o principal mecanismo de degradação no modelo estudado;

9. A superexpressão de $\mathrm{VAPB}^{\mathrm{WT}}$ e $\mathrm{VAPB}^{\mathrm{P} 56 \mathrm{~S}}$ leva a um aumento na expressão de diferentes componentes das subunidades do proteassomo, o que favorece o aumento de atividade do proteassomo na linhagem expressando $\mathrm{VAPB}^{\mathrm{WT}}$ e uma diminuição do 
total de proteínas ubiquitinadas. Na linhagem expressando $\mathrm{VAPB}^{\mathrm{P} 56 \mathrm{~S}}$ a atividade do proteassomo está diminuída e há acúmulo de proteínas ubiquitinadas. O aumento no estresse do RE é sugerido como possível causa na diminuição da atividade nesta linhagem;

10. Marcadores da UPR e do estresse do RE estão alterados nas linhagens expressando a proteína mutante, sugerindo, em conjunto com os dados de degradação proteica, uma grande alteração na proteostase celular;

11. O aumento da expressão de Tsa1 é capaz de atenuar o fenótipo de toxicidade apresentado pela proteína mutante devido, provavelmente, a uma atividade chaperona que facilite a desagregação e encaminhamento das proteínas para a degradação. 


\section{REFERÊNCIAS BIBLIOGRÁFICAS}

Al-Chalabi, A.; Andersen, P. M.; Nilsson, P.; Chioza, B.; Andersson, J. L.; Russ, et al. (1999). Deletions of the heavy neurofilament subunit tail in amyotrophic lateral sclerosis. Human Molecular Genetics 8: 157-64.

Aliaga, L.; Lai, C.; Yu, J.; Chub, N.; Shim, H.; Sun, L.; et al. (2013). Amyotrophic lateral sclerosisrelated VAPB P56S mutation differentially affects the function and survival of corticospinal and spinal motor neurons. Human Molecular Genetics, 22 (21): 4293-4305.

Amarilio, R.; Ramachandran, S.; Sabanay, H.; Lev, S. (2005). Differential regulation of endoplasmic reticulum structure through VAP-Nir protein interaction. Journal of Biological Chemistry 280: 5934-5944.

Andersen, P. M.; Al-Chalabi, A. (2011). Clinical genetics of amyotrophic lateral sclerosis: what do we really know? Nature Reviews Neurology 7: 603-15.

Appenzeller-Herzog, C. (2011). Glutathione- and non-glutathione-based oxidant control in the endoplasmic reticulum. J. Cell Sci. 124: 847-855.

Armakola, M.; Higgins, M. J.; Figley, M. D.; Barmada, S. J.; Scarborough, E. A.; Diaz, Z.; et al. (2012). Inhibition of RNA lariat debranching enzyme suppresses TDP-43 toxicity in ALS disease models. Nature Genetics 44(12): 1302-1309.

Armon, C. (2003). An evidence-based medicine approach to the evaluation of the role of exogenous risk factors in sporadic amyotrophic lateral sclerosis. Neuroepidemiology 22 : 217-228.

Armon, C. (2009). Smoking may be considered an established risk factor for sporadic ALS. Neurology 73(20): 1693-1698.

Atkin, J. D.; Farg, M. A.; Walker, A. K.; McLean, C.; Tomas, D.; Horne, M. K. (2008). Endoplasmic reticulum stress and induction of the unfolded protein response in human sporadic amyotrophic lateral sclerosis. Neurobiol. Dis. 30: 400-407.

Balaban, R. S.; Nemoto, S.; Finkel, T. (2005). Mitochondria, oxidants, and aging. Cell 120: 483495.

Barber S. C.; Mead, R. J.; Shaw P. J. (2006). Oxidative stress in ALS: a mechanism of neurodegeneration and a therapeutic target. Biochim. Biophys. Acta 1762: 1051-1067.

Barber, S. C.; Shaw, P. J. (2010). Oxidative stress in ALS: key role in motor neuron injury and therapeutic target. Free Radical Biology and Medicine 48: 629-641.

Barnham, K. J.; Masters, C. L.; Bush, A. I. (2004). Neurodegenerative diseases and oxidative stress. Nat. Rev. Drug Discov. 3: 205-214.

Baron, Y.; Pedrioli, P. G.; Tyagi, K.; Johnson, C.; Wood, N. T.; Fountaine, D.; Alexandru, G. (2014). VAPB/ALS8 interacts with FFAT-like proteins including the p97 cofactor FAF1 and the 
ASNA1 ATPase. BMC Biology 12: 39.

Bartoszewski, R.; Rab, A.; Jurkuvenaite, A.; Mazur, M.; Wakefield, J.; Collawn, J. F.; Bebok, Z. (2008). Activation of the unfolded protein response by F508 CFTR. Am J Respir Cell Mol Biol 39: 448-457.

Bayne, A.-C. V.; Mockett, R. J.; Orr, W. C.; Sohal, R. S. (2005). Enhanced catabolism of mitochondrial superoxide/hydrogen peroxide and aging in transgenic Drosophila. Biochemical Journal 391: 277-284.

Belzil, V. V.; Daoud, H.; Camu, W.; Strong, M. J.; Dion, P. A.; Rouleau, G. A. (2013). Genetic analysis of SIGMAR1 as a cause of familial ALS with dementia. European Journal of Human Genetics. 21(2): 237-239.

Berthod, F.; Gros-Louis, F. (2012). In Vivo and In Vitro Models to Study Amyotrophic Lateral Sclerosis. Amyotrophic Lateral Sclerosis, Prof. Martin Maurer (Ed.), InTech, DOI: $10.5772 / 39076$.

Bhandary, B.; Marahatta, A.; Kim, H.-R.; Chae, H.-J. (2013). An Involvement of Oxidative Stress in Endoplasmic Reticulum Stress and Its Associated Diseases. International Journal of Molecular Sciences 14(1): 434-456.

Bonnefoy, M; Drai, J.; Kostka, T. (2002). Antioxidants to slow aging, facts and perspectives. Presse Med. 31: 174-184.

Borella, M. L. L.; Varela, Q. D. (2004). Antioxidantes enzimáticos. In-Radicais livres e a resposta celular ao estresse oxidativo. ed. Salvador, M.; Henrique, J.A.P. da Ulbra, Canoas, pp. 35-50.

Boylan, K. (2015). Familial Amyotrophic Lateral Sclerosis. Neurololgy Clinic 33: 807-30.

Braun, R. J.; Sommer, C.; Carmona-Gutierrez, D.; Khoury, C. M.; Ring, J.; Büttner, S.; Madeo, F. (2011). Neurotoxic 43-kDa TAR DNA-binding Protein (TDP-43) Triggers Mitochondrion-dependent Programmed Cell Death in Yeast. Journal of Biological Chemistry 286(22): 19958-19972.

Bryson, H. M.; Fulton, B.; Benfield, P. (1996). Riluzole: a review of its pharmacodynamic and pharmacokinetic properties and therapeutic potential in amyotrophic lateral sclerosis. Drugs 52(4): 549-63.

Cai, H.; Lin, X.; Xie, C.; Laird, F. M.; Lai, C.; Wen, H.; et al. (2005). Loss of ALS2 function is insufficient to trigger motor neuron degeneration in knock-out mice but predisposes neurons to oxidative stress. Journal of Neuroscience 25: 7567-7574.

Calini, D.; Corrado, L.; Del Bo, R.; Gagliardi, S.; Pensato, V.; Verde, F.; et al. (2013). Analysis of hnRNPA1, A2/B1, and A3 genes in patients with amyotrophic lateral sclerosis. Neurobiology of Aging 34: 2695.e11-2.

Cebollero, E.; van der Vaart, A.; Zhao, M.; Rieter, E.; Klionsky, D. J.; Helms, J. B.; Reggiori, F. (2012). Phosphatidylinositol-3-Phosphate Clearance Plays a Key Role in Autophagosome Completion. Current Biology : CB, 22(17), 1545-1553. 
Chae, H.; Kim, I.; Kim, K.; Rhee, S. (1993). Cloning, sequencing, and mutation of thiol-specific antioxidant gene of Saccharomyces cerevisiae. Journal of Biological Chemistry 268(22): $16815-16821$.

Chau, V.; Tobias, J. W.; Bachmair, A.; Marriott, D.; Ecker, D. J.; Gonda, D.K.; Varshavsky, A. (1989). A multiubiquitin chain is confined to specific lysine in a targeted short-lived protein. Science 243: 1576-1583.

Chen, G.; Chen, Z.; Hu, Y.; Huang, P. (2011). Inhibition of mitochondrial respiration and rapid depletion of mitochondrial glutathione by beta-phenethyl isothiocyanate: mechanisms for anti-leukemia activity. Antioxid. Redox Signal. 15: 2911-2921.

Chen, H.-J.; Anagnostou, G.; Chai, A.; Withers, J.; Morris, A.; Adhikaree, J.; Pennetta, G.; de Belleroche, J. S. (2010). Characterization of the properties of a novel mutation in VAPB in familial amyotrophic lateral sclerosis. Journal of Biological Chemistry 285: 40266-40281

Chen, Y. A.; Scheller, R. H. (2001). SNARE-mediated membrane fusion. Nature Reviews in Molecular Cell Biology 2: 98-106.

Chen, Y. Z.; Bennett, C. L.; Huynh, H. M.; Blair, I. P.; Puls, I.; Irobi, J.; et al. (2004). DNA/RNA helicase gene mutations in a form of juvenile Amyotrophic Lateral Sclerosis (ALS4). American Journal of Human Genetics 74(6): 1128-1135.

Chieia, M. A. T. (2005). Doenças do neurônio motor. Neurociências 13(3): 26-30.

Chiò, A.; Logroscino, G.; Traynor, B. J.; Collins, J.; Simeone, J. C.; Goldstein, L. A.; Whitef, L. A. (2013). Global Epidemiology of Amyotrophic Lateral Sclerosis: a Systematic Review of the Published Literature. Neuroepidemiology 41(2): 118-130.

Chow, C. Y.; Landers, J. E.; Bergren, S. K.; Sapp, P. C.; Grant, A. E.; Jones, J. M.; et al. (2009). Deleterious Variants of FIG4, a Phosphoinositide Phosphatase, in Patients with ALS. American Journal of Human Genetics 84(1): 85-88.

Coatti, G. C.; Beccari, M. S.; Olavio, T. R.; Mitne-Neto, M.; Okamoto, O. K.; Zatz, M. (2015). Stem cells for amyotrophic lateral sclerosis modeling and therapy: myth or fact? Cytometry A 87: 197-211.

Collins, G. A.; Gomez, T. A.; Deshaies, R. J.; Tansey, W. P. (2010). Combined chemical and genetic approach to inhibit proteolysis by the proteasome. Yeast 27(11): 965-974.

Coppedè, F. (2011). An Overview of DNA Repair in Amyotrophic Lateral Sclerosis. The Scientific World Journal 11: 1679-1691.

Couthouis, J.; Hart, M. P.; Shorter, J.; De Jesus-Hernandez, M.; Erion, R.; Oristano, R., Gitler, A. D. (2011). A yeast functional screen predicts new candidate ALS disease genes. PNAS 108(52): 20881-20890.

Cox, L. E.; Ferraiuolo, L.; Goodall, E. F.; Heath, P. R.; Higginbottom, A.; Mortiboys, H.; et al. (2010). Mutations in CHMP2B in lower motor neuron predominant Amyotrophic Lateral Sclerosis (ALS). PLoS One 5(3): e9872. 
Cudkowicz, M.; Qureshi, M.; Shefner, J. (2004). Measures and markers in amyotrophic lateral sclerosis. Neuro Rx 1: 273-283.

D’Amico, E.; Factor-Litvak, P.; Santella, R. M.; Mitsumoto, H. (2013). Clinical perspective of oxidative stress in sporadic ALS. Free radical biology \& medicine 65: 10.1016.

De Vos, K. J.; Mórotz, G. M.; Stoica, R.; Tudor, E. L.; Lau, K. F.; Ackerley, S.; et al. (2012). VAPB interacts with the mitochondrial protein PTPIP51 to regulate calcium homeostasis. Human Molecular Genetics 21(6): 1299-1311.

Deffieu, M.; Bhatia-Kiššová, I.; Salin, B.; Galinier, A.; Manon, S.; Camougrand, N. (2009). Glutathione Participates in the Regulation of Mitophagy in Yeast. The Journal of Biological Chemistry 284(22): 14828-14837.

Deng, H. X.; Chen, W.; Hong, S. T.; Boycott, K. M.; Gorrie, G. H.; Siddique, N.; et al. (2011) Mutations in UBQLN2 cause dominant X-linked juvenile and adult-onset ALS and ALS/dementia. Nature 477: 211-215.

Dickinson, D. A.; Forman, H. J. (2002). Glutathione in defense and signaling: Lessons from a small thiol. Ann. N. Y. Acad. Sci. 973: 488-504.

Dringen, R. (2000). Metabolism and functions of glutathione in brain. Prog. Neurobiol 62: 649671.

Duennwald, M. L.; Lindquist, S. (2008). Impaired ERAD and ER stress are early and specific events in polyglutamine toxicity. Genes \& Development,22(23): 3308-3319.

Dunn, W. A.; Jr Cregg, J. M.; Kiel, J. A.; van der Klei, I. J.; Oku, M.; Sakai, Y.; Sibirny, A. A.; Stasyk, O. V.; Veenhuis, M. (2005). Pexophagy: the selective autophagy of peroxisomes. Autphagy 1: 75-83.

Elden, A. C.; Kim, H.-J.; Hart, M. P.; Chen-Plotkin, A. S.; Johnson, B. S.; Fang, X.; et al. (2010). Ataxin-2 intermediate-length polyglutamine expansions are associated with increased risk for ALS. Nature, 466 (7310): 1069-1075.

Escusa-Toret, S.; Vonk, W. I.; Frydman, J. (2013). Spatial sequestration of misfolded proteins by a dynamic chaperone pathway enhances cellular fitness during stress. Nat. Cell Biol. 15: 1231-1243.

Farg, M. A.; Soo, K. Y.; Walker, A. K.; Pham, H.; Orian, J.; Horne, M. K.; et al. (2012). Mutant FUS induces endoplasmic reticulum stress in amyotrophic lateral sclerosis and interacts with protein disulfide-isomerase. Neurobiol. Aging 33, 2855-2868.

Farg, M. A.; Sundaramoorthy, V.; Sultana, J. M.; Yang, S.; Atkinson, R. A. K.; Levina, V.; et al. (2014). C9ORF72, implicated in amytrophic lateral sclerosis and frontotemporal dementia, regulates endosomal trafficking. Human Molecular Genetics 23(13): 3579-3595.

Fasana, E.; Fossati, M.; Ruggiano, A.; Brambillasca, S.; Hoogenraad, C. C.; Navone, F.; et al. (2010). A VAPB mutant linked to amyotrophic lateral sclerosis generates a novel form of organized smooth endoplasmic reticulum. FASEB J. 24: 1419-1430. 
Feissner, R. F.; Skalska, J.; Gaum, W. E.; Sheu, S.-S. (2009). Crosstalk signaling between mitochondrial $\mathrm{Ca}^{2+}$ and ROS. Frontiers in Bioscience: A Journal and Virtual Library, 14, $1197-1218$.

Feldman, D. E.; Chauhan, V.; Koong, A. C. (2005). The unfolded protein response: a novel component of the hypoxic stress response in tumors. Mol Cancer Res 3: 597-605.

Ferraiuolo, L.; Kirby, J.; Grierson, A. J.; Sendtner, M.; Shaw, P. J. (2011). Molecular pathways of motor neuron injury in amyotrophic lateral sclerosis. Nature Reviews Neurology 7: 61630.

Finley, D. (2009). Recognition and Processing of Ubiquitin-Protein Conjugates by the Proteasome. Annual Review of Biochemistry 78: 477-513.

Forrest, S.; Chai, A.; Sanhueza, M.; Marescotti, M.; Parry, K.; Georgiev, A.; Sahota, V.; MendezCastro, R.; Pennetta, G. (2013). Increased levels of phosphoinositides cause neurodegeneration in a Drosophila model of amyotrophic lateral sclerosis. Hum. Mol. Genet. 22: 2689-2704.

Foster, L. J.; Weir, M. L.; Lim, D. Y.; Liu, Z.; Trimble, W. S.; Klip, A. (2000). A functional role for VAP-33 in insulin-stimulated GLUT4 traffic. Traffic 1: 512-521.

Funke, A.; Esser, M.; Krüttgen, A.; Weis, J.; Mitne-Neto, M.; Lazar, M.; et al. (2010). The p.P56S mutation in the $V A P B$ gene is not due to a single founder: the first European case. Clinical Genetics, 77(3), 302-303.

Gass, J. N.; Gifford, N. M.; Brewer, J. W. (2002). Activation of an unfolded protein response during differentiation of antibody-secreting B cells. J Biol Chem 277(50): 49047-49054.

Genevini, P.; Papiani, G.; Ruggiano, A.; Cantoni, L.; Navone, F.; Borgese, N. (2014). Amyotrophic Lateral Sclerosis-Linked Mutant VAPB Inclusions Do Not Interfere with Protein Degradation Pathways or Intracellular Transport in a Cultured Cell Model. PLoS One 9(11): e113416.

Gilgun-Sherki, Y.; Melamed, E.; Offen, D. (2001). Oxidative stress induced-neurodegenerative diseases: The need for antioxidants that penetrate the blood brain barrier. Neuropharmacology 40: 959-975.

Gkogkas, C.; Middleton, S.; Kremer, A. M.; Wardrope, C.; Hannah, M.; Gillingwater, T. H.; Skehel, P. (2008). VAPB interacts with and modulates the activity of ATF6. Hum Mol Genet 17: $1517-1526$.

Glick, B. S.; Pon, L. A. (1995). Isolation of highly purified mitochondria from Saccharomyces cerevisiae. Methods in Enzymology 260: 213-223.

Goffeau, A.; Barrell, B. G.; Bussey, H.; Davis, R. W.; Dujon, B.; Feldmann.; et al. (1996). Life with 6000 genes. Science 274: 546-567.

Greenway, M. J.; Andersen, P. M.; Russ, C.; Ennis, S.; Cashman, S.; Donaghy, C.; et al. (2006). ANG mutations segregate with familial and 'sporadic' amyotrophic lateral 
sclerosis. Nature Genetics 38: 411-413.

Griffith, O. W. (1999). Biologic and pharmacologic regulation of mammalian glutathione synthesis. Free Radic Biol Med. 27: 922-935.

Gunther M. R.; Vangilder R.; Fang J.; Beattie D. S. (2004). Expression of a familial amyotrophic lateral sclerosis-associated mutant human superoxide dismutase in yeast leads to decreased mitochondrial electron transport. Arch. Biochem. Biophys. 431: 207-214.

Halliwell, B.; Gutteridge, J. M. C. (2006). In: Halliwell, B.;Gutteridge, J. M. C. (eds). Free Radicals in Biology and Medicine, Third Ed., Oxford University Press, Oxford

Han, S. M.; Tsuda, H.; Yang, Y.; Vibbert, J.; Cottee, P.; Lee S. J.; et al. (2012). Secreted VAPB/ALS8 major sperm protein domains modulate mitochondrial localization and morphology via growth cone guidance receptors. Dev. Cell. 22: 348-362.

Hansen, J. M.; Zhang, H.; Jones, D. P. (2006). Differential oxidation of thioredoxin-1, thioredoxin2, and glutathione by metal ions. Free Radic. Biol. Med. 40: 138-145.

Hanzén, S.; Vielfort, K.; Yang, J.; Roger, F.; Andersson, V.; et al. (2016). Lifespan Control by Redox-Dependent Recruitment of Chaperones to Misfolded Proteins. Cell 166: 1-12.

Harding, H. P.; Novoa, I.; Zhang, Y.; Zeng, H.; Wek, R.; Schapira, M. (2000). Regulated translation initiation controls stress-induced gene expression in mammalian cells. Molecular Cell. 6: 1099-1108.

Harding, H. P.; Zhang, Y.; Ron, D. (1999). Protein translation and folding are coupled by an endoplasmic-reticulum-resident kinase. Nature 397: 271-274.

Harding, H. P.; Zhang, Y.; Zeng, H.; Novoa, I.; Lu, P. D.; Calfon, M. (2003). An integrated stress response regulates amino acid metabolism and resistance to oxidative stress. Molecular Cell 11: 619-633.

Haynes, C. M.; Titus, E. A.; Cooper, A. A. (2004). Degradation of misfolded proteins prevents ER-derived oxidative stress and cell death. Mol. Cell. 15: 767-776.

Haze, K.; Yoshida, H.; Yanagi, H.; Yura, T.; Mori, K. (1999). Mammalian transcription factor ATF6 is synthesized as a transmembrane protein and activated by proteolysis in response to endoplasmic reticulum stress. Molecular Biology of the Cell 10: 3787-3799.

Hensman Moss, D. J.; Poulter, M.; Beck, J.; Hehir, J.; Polke, J. M.; Campbell, T.; et al. (2014). C9orf72 expansions are the most common genetic cause of Huntington disease phenocopies. Neurology 82: 292-9.

Hirano, M.; Nakamura, Y.; Saigoh, K.; Sakamoto, H.; Ueno, S.; Isono, C.; et al. (2014). VCP gene analyses in Japanese patients with sporadic amyotrophic lateral sclerosis identify a new mutation.Neurobiol. Aging 10.1016/j.neurobiolaging.2014.10.012

Honjo Y.; Kaneko S.; Ito H.; Horibe T.; Nagashima M.; Nakamura M.; et al. (2011). Protein disulfide isomerase-immunopositive inclusions in patients with amyotrophic lateral sclerosis. Amyotroph. Lateral. Scler. 12, 444-450. 
Iraqui, I.; Kienda, G.; Soeur, J.; Faye, G.; Baldacci, G.; Kolodner, R. D.; Huang, M. E. (2009). Peroxiredoxin Tsa1 is the key peroxidase suppressing genome instability and protecting against cell death in Saccharomyces cerevisiae. PLoS Genet. 5 e1000524.

Isler, J. A.; Skalet, A. H.; Alwine, J. C. (2005). Human cytomegalovirus infection activates and regulates the unfolded protein response. J Virol 79.

Ito, D.; Suzuki, N. (2009). Seipinopathy: a novel endoplasmic reticulum stress-associated disease. Brain 132(1): 8-15.

Jang, H. H.; Lee, K. O.; Chi, Y. H.; Jung, B. G.; Park, S. K.; Park, J. H.; et al. (2004). Two enzymes in one; two yeast peroxiredoxins display oxidative stress-dependent switching from a peroxidase to a molecular chaperone function. Cell 117: 625-635.

Jiang, Y.; Rumble, J. L.; Gleixner, A. M.; Unnithan, A. S.; Pulugulla, S. H.; Posimo, J. M.; et al. (2013). N-Acetyl cysteine blunts proteotoxicity in a heat shock protein-dependent manner. Neuroscience. 255: 19-32.

Jin, C.; Reed, J. C. (2002). Yeast and apoptosis. Nature Reviews in Molecular Cell Biology 3: 453459.

Johnson, B. S.; McCaffery, J. M.; Lindquist, S.; Gitler, A. D. (2008). A yeast TDP-43 proteinopathy model: Exploring the molecular determinants of TDP-43 aggregation and cellular toxicity. PNAS 105 (17): 6439-6444.

Johnson, J. O.; Mandrioli, J.; Benatar, M.; Abramzon, Y.; Van Deerlin, V. M.; Trojanowski, J. Q.; et al. (2010) Exome sequencing reveals VCP mutations as a cause of familial ALS. Neuron 68: 857-864.

Johnson, J. O.; Pioro, E. P.; Boehringer, A.; Chia, R.; Feit, H.; Renton, A.; et al. (2014). Mutations in the Matrin 3 gene cause familial amyotrophic lateral sclerosis. Nature Neuroscience 17(5): 664-666.

Johnston, J. A.; Ward, C. L.; Kopito, R. R. (1998). Aggresomes: a cellular response to misfolded proteins. J Cell Biol 143: 1883-1898.

Jones, D. P. (2006). Redefining oxidative stress. Antioxid Redox Signal 8: 1865-1879.

Ju, S.; Tardiff, D. F.; Han, H.; Divya, K.; Zhong, Q.; Maquat, L. E.; et al. (2011). A yeast model of FUS/TLS-dependent cytotoxicity. PLoS Biol. 9: e1001052

Kabashi, E.; El Oussini, H.; Bercier, V.; Gros-Louis, F.; Valdmanis, P. N.; McDearmid, J.; et al. (2013). Investigating the contribution of VAPB/ALS8 loss of function in amyotrophic lateral sclerosis. Human Molecular Genetics 22: 2350-2360.

Kabashi, E.; Valdmanis, P. N.; Dion, P.; Spiegelman, D.; McConkey, B. J.; Vande Velde, C.; et al. (2008). TARDBP mutations in individuals with sporadic and familial amyotrophic lateral sclerosis. Nature Genetics 40: 572-574.

Kaganovich, D.; Kopito, R.; Frydman, J. (2008). Misfolded proteins partition between two distinct 
quality control compartments. Nature 454: 1088-1095.

Kagiwada, S. ; Zen, R. (2003) Role of the yeast VAP homolog, Scs2p, in INO1 expression and phospholipid metabolism. Journal of Biochemistry 133: 515-522.

Kamel, F.; Umbach, D. M.; Bedlack, R. S.; Richards, M.; Watson, M.; Alavanja, M. C.; et al. (2012). Pesticide exposure and amyotrophic lateral sclerosis. Neurotoxicology 33(3) 457-462.

Kamel, F.; Umbach, D. M.; Munsat, T. L.; Shefner, J. M.; Hu, H.; Sandler, D. P. (2003). Lead exposure and amyotrophic lateral sclerosis. Epidemiology 13(3): 311-319.

Kanekura, K.; Nishimoto. I.; Aiso, S.; Matsuoka, M. (2006). Characterization of amyotrophic lateral sclerosis-linked P56S mutation of vesicle-associated membrane protein-associated protein B (VAPB/ALS8). Journal of Biological Chemistry 281: 30223-30233.

Kaya, A.; Lobanov, A. V.; Gerashchenko, M. V.; Koren, A.; Fomenko, D. E.; Koc, A.; Gladyshev, V. N. (2014). Thiol Peroxidase Deficiency Leads to Increased Mutational Load and Decreased Fitness in Saccharomyces cerevisiae. Genetics 198(3): 905-917.

Khurana, V.; Lindquist, S. (2010). Modelling neurodegeneration in Saccharomyces cerevisiae: why cook with baker's yeast? Nature Review in Neuroscience 11(6): 436-9.

Klionsky, D. J. (2005). The molecular machinery of autophagy: unanswered questions. Journal of Cell Science 118 (Pt 1): 7-18.

Knott, A. B.; Perkins, G.; Schwarzenbacher, R.; Bossy-Wetzel, E. (2008). Mitochondrial fragmentation in neurodegeneration. Nature Reviews in Neurosciece 9: 505-518.

Kraft, C.; Reggiori, F.; Peter, M. (2009). Selective types of autophagy in yeast. Biochim. Biophys. Acta 1793: 1404-1412.

Krick, R.; Muehe, Y.; Prick, T.; Bremer, S.; Schlotterhose, P.; Eskelinen, E.-L.; Thumm, M. (2008). Piecemeal Microautophagy of the Nucleus Requires the Core Macroautophagy Genes. Molecular Biology of the Cell 19(10): 4492-4505.

Kuijpers, M.; Yu, K. L.; Teuling, E.; Akhmanova, A.; Jaarsma, D.; Hoogenraad, C. C. (2013). The ALS8 protein VAPB interacts with the ER-Golgi recycling protein YIF1A and regulates membrane delivery into dendrites. The EMBO Journal 32(14): 2056-2072.

Kuzuhara, S.; Kokubo, Y.; Sasaki, R.; Narita, Y.; Yabana, T.; Hasegawa, M.; Iwatsubo, T. (2001). Familial amyotrophic lateral sclerosis and parkinsonism-dementia complex of the Kii Peninsula of Japan: clinical and neuropathological study and tau analysis. Annual Neurolology 49(4): 501-511.

Kwan, J. Y.; Jeong, S. Y.; Van Gelderen, P.; Deng, H.-X.; Quezado, M. M.; Danielian, L. E.; et al. (2012). Iron Accumulation in Deep Cortical Layers Accounts for MRI Signal Abnormalities in ALS: Correlating 7 Tesla MRI and Pathology. PLoS ONE 7(4): e35241.

Labbadia, J.; Morimoto, R. I. (2015). The Biology of Proteostasis in Aging and Disease. Annual Review of Biochemistry 84: 435-464.

Lacomblez, L.; Bensimon, G.; Leigh, P. N.; Guillet, P.; Meininger, V. (1996). Dose-ranging study of 
riluzole in amyotrophic lateral sclerosis. Amyotrophic Lateral Sclerosis/Riluzole Study Group II. Lancet. 347 (9013): 1425-31.

Lai, C.; Xie, C.; Shim, H.; Chandran, J.; Howell, B. W.; Cai, H. (2009). Regulation of endosomal motility and degradation by amyotrophic lateral sclerosis 2/alsin. Molecular Brain 2: 23.

Larroquette. F.; Seto, L.; Gaub, P. L.; Kamal, B.; Wallis, D.; Larivière, R.; et al. (2015). Vapb/Amyotrophic lateral sclerosis 8 knock-in mice display slowly progressive motor behavior defects accompanying ER stress and autophagic response. Hum. Mol. Genet. 24: 6515-6529.

Lee, A. S. (1992). Mammalian stress response: induction of the glucose-regulated protein family. Curr Opin Cell Biol 4: 267-273.

Lee, S.; Tak, E.; Lee, J.; Rashid, M.; Murphy, M. P.; Ha, J.; Kim, S. S. (2011). Mitochondrial $\mathrm{H}_{2} \mathrm{O}_{2}$ generated from electron transport chain complex I stimulates muscle differentiation. Cell Research 21(5): 817-834.

Lefebvre, S. Burglen, L.; Reboullet, S.; Clermont, O.; Burlet, P.; Viollet L.; et al. (1995). Identification and characterization of a spinal muscular atrophy-determining gene. Cell 80: $155-165$.

Lehman, E. J.; Hein, M. J.; Baron, S. L.; Gersic, C. M. (2012). Neurodegenerative causes of death among retired National Football League players. Neurology 79(19): 1970-1974.

Lesage, S.; Le Ber, I.; Condroyer, C.; Broussolle, E.; Gabelle, A.; Thobois, S.; et al. (2013). C9orf72 repeat expansions are a rare genetic cause of parkinsonism. Brain 136: 385-91.

Lev, S.; Ben Halevy, D.; Peretti, D.; Dahan, N. (2008). The VAP protein family: from cellular functions to motor neuron disease. Trends Cell Biol. 18: 282-290.

Li, H-F.; Wu, Z-Y. (2016). Genotype-phenotype correlations of amyotrophic lateral sclerosis. Translational Neurodegeneration 5: 3.

Lipson, K. L.; Fonseca, S. G.; Ishigaki, S.; Nguyen, L. X.; Foss, E.; Bortell, R.; Rossini, A. A.; Urano, F. (2006). Regulation of insulin biosynthesis in pancreatic beta cells by an endoplasmic reticulum-resident protein kinase IRE1. Cell Metab 4: 245-254.

Loewen, C. J.R.; Roy, A.; Levine, T. P. (2003). A conserved ER targeting motif in three families of lipid binding proteins and in Opi1p binds VAP. EMBO Journal 22(9): 2025-2035.

Ma, Y.; Brewer, J. W.; Diehl, J. A.; Hendershot, L. M. (2002). Two distinct stress signaling pathways converge upon the CHOP promoter during the mammalian unfolded protein response. Journal of Molecular Biology 318: 1351-1365.

MacDiarmid, C. W.; Taggart, J.; Kerdsomboon, K.; Kubisiak, M.; Panascharoen, S.; Schelble, K.; Eide, D. J. (2013). Peroxiredoxin Chaperone Activity Is Critical for Protein Homeostasis in Zinc-deficient Yeast. The Journal of Biological Chemistry 288(43): 31313-31327.

Majounie, E.; Abramzon, Y.; Renton, A. E.; Perry, R.; Bassett, S. S.; Pletnikova, O.; et al. (2012). Repeat expansion in C9ORF72 in Alzheimer's disease. New England Journal of Medicine 
366: $283-4$.

Malhotra, J. D.; Kaufman, R. J. (2007). The Endoplasmic Reticulum and the Unfolded Protein Response. Seminars in Cell \& Developmental Biology 18(6): 716-731.

Malinovska, L.; Kroschwald, S.; Murder, M. C.; Richter, D.; Alberti, S. (2012). Molecular chaperones and stress-inducible protein-sorting factors coordinate the spatiotemporal distribution of protein aggregates. Mol Cell Biol 23: 3041-3056.

Mancuso, R.; Navarro, X. (2015). Amyotrophic lateral sclerosis: current perspectives from basic research to the clinic. Progress in Neurobiology 133: 1-26.

Marangi, G; Traynor, B. J. (2014). Genetic causes of amyotrophic lateral sclerosis: new genetic analysis methodologies entailing new opportunities and challenges. Brain Research. http://dx.doi.org/10.1016/j.brainres.2014.10.009.

Martens, S.; Bachmair, A. (2015). How cells coordinate waste removal through their major proteolytic pathways. Nature Cell Biology 17: 841-842.

Maruyama, H.; Morino, H.; Ito, H.; Izumi, Y.; Kato, H.; Watanabe, Y.; et al. (2010). Mutations of optineurin in amyotrophic lateral sclerosis. Nature 465: 223-226.

Menendez-Benito, V.; Verhoef, L. G.; Masucci, M. G.; Dantuma N. P. (2005). Endoplasmic reticulum stress compromises the ubiquitin-proteasome system. Hum Mol Genet 14: 2787-2799.

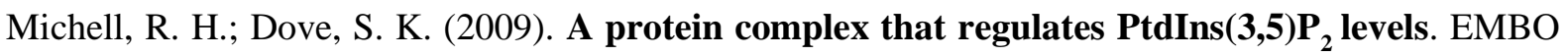
J. 28: 86-87 (2009).

Millecamps, S.; Salachas, F.; Cazeneuve, C.; Gordon, P.; Bricka, B.; Camuzat, A.; et al. (2010). SOD1, ANG, VAPB, TARDBP, and FUS mutations in familial amyotrophic lateral sclerosis: genotype-phenotype correlations. Journal of Medical Genetics 47: 554560.

Mitchell, J.; Paul, P.; Chen, H. J.; Morris, A.; Payling, M.; Falchi, M.; et al. (2010). Familial amyotrophic lateral sclerosis is associated with a mutation in D-amino acid oxidase. PNAS 107: 7556-7561.

Mitne-Neto, M.; Machado-Costa, M.; Marchetto, M. C. N.; Bengtson, M. H.; Joazeiro, C. A.; Tsuda, H.; et al. (2011). Downregulation of VAPB expression in motor neurons derived from induced pluripotent stem cells of ALS8 patients. Human Molecular Genetics 20(18): 36423652 .

Mori, K. (2009). Signalling pathways in the unfolded protein response: development from yeast to mammals. J. Biochem. 146: 743-750.

Morotz, G. M.; De Vos, K. J.; Vagnoni, A.; Ackerley, S.; Shaw, C. E.; Miller, C. C. J. (2012). Amyotrophic lateral sclerosis-associated mutant VAPBP56S perturbs calcium homeostasis to disrupt axonal transport of mitochondria. Human Molecular Genetics 21: 1979-1988. 
Moumen, A.; Virard, I.; Raoul, C. (2011). Accumulation of Wildtype and ALS-Linked Mutated VAPB Impairs Activity of the Proteasome. PLoS ONE 6(10): e26066.

Moustaqim-Barrette, A., Lin, Y. Q., Pradhan, S., Neely, G. G., Bellen, H. J., \& Tsuda, H. (2014). The amyotrophic lateral sclerosis 8 protein, VAP, is required for ER protein quality control. Human Molecular Genetics 23(8), 1975-1989.

Muyderman, H.; Chen, T. (2014). Mitochondrial dysfunction in amyotrophic lateral sclerosis - a valid pharmacological target? British Journal of Pharmacology 171(8): 2191-2205.

Nakatogawa, H.; Suzuki, K.; Kamada, Y.; Ohsumi, Y. (2009). Dynamics and diversity in autophagy mechanisms: lessons from yeast. Nature Rev. Mol. Cell Biol. 10: 458-467.

Nakatsukasa, K.; Kamura, T.; Brodsky, J. L. (2014). Recent technical developments in the study of ER-associated degradation. Current Opinion in Cell Biology 0: 82-91.

Nazıroğlu, M.; Senol, N.; Ghazizadeh, V.; Yürüker, V. (2014). Neuroprotection induced by Nacetylcysteine and selenium against traumatic brain injury-induced apoptosis and calcium entry in hippocampus of rat. Cell. Mol. Neurobiol. 34(6): 895-903.

Nikawa, J.; Akiyoshi, M.; Hirata, S.; Fukuda, T. (1996). Saccharomycescerevisiae IRE2/HAC1 is involved in IRE1-mediated KAR2 expression. Nucleic Acids Res 24: 4222-4226.

Nishimura, A. L.; Al-Chalabi, A.; Zatz, M. (2005). A common founder for amyotrophic lateral sclerosis type 8 (ALS8) in the Brazilian population. Human Genetics 118: 499-500.

Nishimura, A. L.; Mitne-Neto, M.; Silva, H. C.; Richieri-Costa, A.; Middleton, S.; Cascio, D.; Kok, F.; Oliveira, J. R.; Gillingwater, T.; Webb, J.; Skehel, P.; Zatz, M. (2004). A mutation in the vesicle-trafficking protein VAPB causes late-onset spinal muscular atrophy and amyotrophic lateral sclerosis. American journal of human genetics 75: 822-831.

Nishimura, Y.; Hayashi, M.; Inada, H.; Tanaka, T. (1999). Molecular cloning and characterization of mammalian homologues of vesicle-associated membrane protein-associated (VAMPassociated) proteins. Biochem. Biophys. Res. Commun. 254: 21-26.

Oikawa, D.; Kimata, Y.; Kohno, K.; Iwawaki, T. (2009). Activation of mammalian IRE1alpha upon ER stress depends on dissociation of BiP rather than on direct interaction with unfolded proteins.Exp Cell Res 315(15): 2496-2504.

Panov, A.; Kubalik, N.; Zinchenko, N.; Hemendinger, R.; Dikalov, S.; Bonkovsky, H.L. (2011). Respiration and ROS production in brain and spinal cord mitochondria of transgenic rats with mutant G93A Cu/Zn-Superoxide dismutase gene. Neurobiol. Dis. 44: 53-62

Papiani, G.; Ruggiano, A.; Fossati, M.; Raimondi, A.; Bertoni, G.; Francolini, M.; et al. (2012). Restructured endoplasmic reticulum generated by mutant amyotrophic lateral sclerosislinked VAPB is cleared by the proteasome. J. Cell Sci. 125: 3601-3611.

Parkinson, N.; Ince, P. G.; Smith, M. O.; Highley, R.; Skibinski, G.; Andersen, P. M.; et al. (2006).

ALS phenotypes with mutations in CHMP2B (charged multivesicular body protein 2B). Neurology 67: 1074-1077. 
Pasinelli, P.; Brown, R. H. (2006). Molecular biology of amyotrophic lateral sclerosis: insights from genetics. Nature Reviews of Neuroscience 7: 710-723.

Pedrajas, J. R.; Padilla, C.; McDonagh, B.; Barcena, J. A. (2010). Glutaredoxin participates in the reduction of peroxides by the mitochondrial 1-CYS peroxiredoxin in Saccharomyces cerevisiae. Antioxid Redox Signal. 13: 249-258.

Pennetta, G.; Hiesinger, P. R.; Fabian-Fine, R.; Meinertzhagen, I. A.; Bellen, H. J. (2002). Drosophila VAP-33A directs bouton formation at neuromuscular junctions in a dosagedependent manner. Neuron 35, 291-306.

Pereira, C.; Coutinho, I.; Soares, J.; Bessa, C.; Leão, M.; Saraiva, L. (2012). New insights into cancer-related proteins provided by the yeast model. FEBS Journal 279(5): 697-712.

Plato, C. C.; Garruto, R. M.; Galasko, D.; Craig, U. K.; Plato, M.; Gamst, A.; et al. (2003). Amyotrophic lateral sclerosis and parkinsonism-dementia complex of Guam: changing incidence rates during the past 60 years. American Journal of Epidemiology 57: 149-57.

Powers, E. T.; Morimoto, R. I.; Dillin, A.; Kelly, J. W.; Balch, W. E. (2009). Biological and chemical approaches to diseases of proteostasis deficiency. Annu Rev Biochem 78: 959-91.

Preuss, D.; Mulholland, J.; Kaiser, C. A.; Orlean, P.; Albright, C.; Rose, M. D.; Robbins, P. W.; Botstein, D. (1991). Structure of the yeast endoplasmic reticulum: localization of ER proteins using immunofluorescence and immunoelectron microscopy. Yeast 7: 891-911.

Rabizadeh, S.; Gralla, E. B.; Borchelt, D. R.; Gwinn, R.; Valentine, J. S.; Sisodia, S.; et al. (1995). Mutations associated with amyotrophic lateral sclerosis convert superoxide dismutase from an antiapoptotic gene to a proapoptotic gene: studies in yeast and neural cells. PNAS $92(7)$, 3024-3028.

Rao, M.; Song, W.; Jiang, A.; Shyr, Y.; Lev, S.; Greenstein, D.; et al. (2012). VAMP-Associated Protein B (VAPB) Promotes Breast Tumor Growth by Modulation of Akt Activity. PLoS ONE 7(10): e46281.

Ratnaparkhi, A.; Lawless, G. M.; Schweizer, F. E.; Golshani, P.; Jackson, G. R. (2008).

A Drosophila Model of ALS: Human ALS-Associated Mutation in VAP33A Suggests a Dominant Negative Mechanism. PLoS ONE 3(6): e2334.

Renton, A. E.; Chiò, A.; Traynor, B. J. (2014). State of play in amyotrophic lateral sclerosis genetics. Nature neuroscience. 17(1): 17-23.

Renton, A. E.; Majounie, E.; Waite, A. (2012). A hexanucleotide repeat expansion inC9ORF72 is the cause of chromosome 9p21-linked ALS-FTD. Neuron 72(2): 257-268.

Rieder, S. E.; Emr, S. D. (2001). Isolation of subcellular fractions from the yeast Saccharomyces cerevisiae. Curr Protoc Cell Biol. Unit 3.7.

Ringholz, G. M.; Appel, S. H.; Bradshaw, M.; Cooke, N. A.; Mosnik, D. M.; Schulz, P. E. (2005). Prevalence and patterns of cognitive impairment in sporadic ALS. Neurology 65: 586-590. Robberecht, W.; Philips, T. (2013). The changing scene of amyotrophic lateral sclerosis. Nature 
Reviews Neuroscience 14: 248-64.

Ron, D. (2002). Translational control in the endoplasmic reticulum stress response. The Journal of Clinical Investigation 110: 1383-1388.

Roos, P. M.; Lierhagen, S.; Flaten, T. P.; Syversen, T.; Vesterberg, O.; Nordberg, M. (2012). Manganese in cerebrospinal fluid and blood plasma of patients with amyotrophic lateral sclerosis. Exp Biol Med 237(7): 803-810.

Rosen, D. R.; Siddique, T.; Patterson, D.; Figlewicz, D. A. Sapp, P.; Hentati, A.; et al. (1993). Mutations in $\mathrm{Cu} / \mathrm{Zn}$ superoxide dismutase gene are associated with familial amyotrophic lateral sclerosis. Nature 362: 59-62.

Ruggiano, A.; Foresti, O.; Carvalho, P. (2014). ER-associated degradation: Protein quality control and beyond. The Journal of Cell Biology, 204(6), 869-879.

Russ, W. P.; Engelman, D. M. (2000). The GxxxG motif: a framework for transmembrane helixhelix association. Journal of Molecular Biology 296: 911-919.

Sasaki, S.; Iwata, M. (2007). Mitochondrial alterations in the spinal cord of patients with sporadic amyotrophic lateral sclerosis. Journal of Neuropathology 66: 10-16.

Scherrer, K. Darnell, J. E. (1962). Sedimentation characteristics of rapidly labelled RNA from HeLa cells. Biochem Biophys Res Commun. 47: 486-490.

Schiestl, R. H.; Gietz, R. D. (1989). High efficiency transformation of intact yeast cells using single stranded nucleic acids as a carrier. Curr Genet. 16(5-6): 339-46.

Schröder, M. (2008). Endoplasmic reticulum stress responses. Cell Mol. Life Sci. 65: 862-894.

Sevier, C. S.; Kaiser, C. A. (2008). Ero1 and redox homeostasis in the endoplasmic reticulum. Biochim Biophys Acta. 1783: 549-556.

Sharma, N.; Brandis, K. A.; Herrera, S. K.; Johnson, B. E.; Vaidya, T.; Shrestha, R. (2006). Alphasynuclein budding yeast model: Toxicity enhanced by impaired proteasome and oxidative stress. Journal of molecular neuroscience 28: 161-178.

Shetty, P.; Pradhan, S.; Viswanathan, C. (2015). Stem Cell strategy for the treatment of Motor Neuron Diseases. Journal of Stem Cells Regeneration Medicine 2(1): 002.

Sidrauski, C.; Walter, P. (1997). The transmembranekinase Ire1p is a site-specific endonuclease that initiates mRNA splicing in the unfolded protein response. Cell 90: 1031-1039.

Skehel, P. A.; Martin, K. C.; Kandel, E. R.; Bartsch, D. A. (1995). VAMP-binding protein from Aplysia required for neurotransmitter release. Science 269: 1580-1583.

Smith, B. N.; Newhouse, S.; Shatunov, A.; Vance, C.; Topp, S.; Johnson, L.; et al. (2013). The C9ORF72 expansion mutation is a common cause of ALS+/-FTD in Europe and has a single founder. European Journal of Humam Genetics 21: 102-8.

Smith, M. G.; Snyder, M. (2006). Yeast as a model for human disease. Curr Protoc Hum Genet. doi: 10.1002/0471142905.hg1506s48.

Sontag, E. M.; Vonk, W. I. M.; Frydman, J. (2014). Sorting out the trash: the spatial nature of 
eukaryotic protein quality control. Cell Biol 26: 139-146.

Soto, C.; Estrada, L.D. (2008). Protein misfolding and neurodegeneration. Arch Neurol 65: 184189.

Specht, S.; Miller, S. B.; Mogk, A.; Bukau, B. (2011). Hsp42 is required for sequestration of protein aggregates into deposition sites in Saccharomyces cerevisiae. J Cell Biol 195: 617629.

Sullivan P.G.; Rabchevsky, A.G.; Keller, J.Y.N.; Lovell, M.; Sodhi, A.; Hart, R.P.; Scheffer, S.W. (2004). Intrinsic differences in brain and spinal cord mitochondria: implication for therapeutic interventions. J. Comparative Neurol. 474: 524-534

Sun, Z.; Diaz, Z.; Fang, X.; Hart, M. P.; Chesi, A.; Shorter, J.; Gitler, A. D. (2011). Molecular

Determinants and Genetic Modifiers of Aggregation and toxicity for the ALS Disease Protein FUS/TLS. PLoS Biology 9(4): e1000614.

Suzuki, H.; Kanekura, K.; Levine, T. P.; Kohno, K.; Olkkonen, V. M.; Aiso, S.; Matsuoka, M. (2009).

ALS linked P56S-VAPB, an aggregated loss-of-function mutant of VAPB, predisposes motor neurons to ER stress-related death by inducing aggregation of co-expressed wildtype VAPB. J Neurochim 108: 973-985.

Szegezdi, E.; Logue, S. E.; Gorman, A. M.; Samali, A. (2006). Mediators of endoplasmic reticulum stress-induced apoptosis. EMBO reports 7: 880-885.

Teuling, E.; Ahmed, S.; Haasdijk, E.; Demmers, J.; Steinmetz, M. O.; Akhmanova, A.; et al. (2007).

Motor neuron disease-associated mutant vesicle-associated membrane protein-associated protein (VAP) B recruits wild-type VAPs into endoplasmic reticulum-derived tubular aggregates. Journal of Neuroscience 27: 9801-9815.

Tran, J. R.; Brodsky, J. L. (2012). Assays to Measure ER-Associated Degradation in Yeast. Methods in Molecular Biology 832: 505-518.

Tsuda, H.; Han, S.M.; Yang, Y.; Tong, C.; Lin, Y. Q.; Mohan, K.; et al. (2008). The amyotrophic lateral sclerosis 8 protein VAPB is cleaved, secreted, and acts as a ligand for Eph receptors. Cell 133: 963-977.

Tu, B. P.; Weissman, J. S. (2004). Oxidative protein folding in eukaryotes: mechanisms and consequences. The Journal of Cell Biology, 164(3), 341-346.

Tudor, E. L.; Galtrey, C.M.; Perkinton, M. S.; Lau, K. F.; De Vos, K. J.; Mitchell, J. C. et al. (2010). Amyotrophic lateral sclerosis mutant vesicle associated membrane protein-associated protein-B transgenic mice develop TAR DNA-binding protein-43 pathology. Neuroscience. 167: 774-785.

Turner, M. R. (2013). Increased premorbid physical activity and amyotrophic lateral sclerosis: born to run rather than run to death, or a seductive myth? Journal of Neurology, Neurosurgery and Psychiatry 84(9): 947.

Tyedmers, J.; Mogk, A.; Bukau, B. (2010). Cellular strategies for controlling protein aggregation. 
Nat Rev Mol Cell Biol, 11: 777-788.

Unnithan, A. S.; Choi, H. J.; Titler, A. M.; Posimo, J. M.; Leak, R. K. (2012). Rescue from a two hit, high-throughput model of neurodegeneration with $\mathbf{N}$-acetyl cysteine. Neurochem. Int. 61 : $356-368$.

Van Blitterswijk, M.; Van Es, M. A.; Koppers, M.; Van Rheenen, W.; Medic, J.; Schelhaas, H. J.; et al. (2012). VAPB and C9orf72 mutations in 1 familial amyotrophic lateral sclerosis patient. Neurobiology of Aging 33: e1-e4.

Van Damme, P.; Dewil, M.; Robberecht, W.; Van den Bosch, L. (2005). Excitotoxicity and amyotrophic lateral sclerosis. Neurodegenertive Diseases 2: 147-159.

Vance, C.; Rogelj, B.; Hortobágyi, T.; De Vos, K. J.; Nishimura, A. L.; Sreedharan, J.; et al. (2009). Mutations in FUS, an RNA processing protein, cause Familial Amyotrophic Lateral Sclerosis Type 6. Science (5918): 1208-1211.

Vande Velde, C.; Miller, T. M.; Cashman, N. R.; Cleveland, D. W. (2008). Selective association of misfolded ALS-linked mutant SOD1 with the cytoplasmic face of mitochondria. Proc. Natl Acad. Sci. 105: 4022-4027.

Vembar, S. S.; Brodsky, J. L. (2008). One step at a time: endoplasmic reticulum-associated degradation. Nature Reviews. Molecular Cell Biology 9(12): 944-957.

Vilariño-Güell, C.; Wider, C.; Soto-Ortolazza, A. I.; Cobb, S. A.; Kachergus, J. M.; Keeling, B. H.; et al. (2009). Characterization of DCTN1 genetic variability in neurodegeneration. Nurology 72: 2024-2028.

Walberg, M. W. (2000). Applicability of yeast genetics to neurologic disease. Archives in Neurolog 57(8): 1129-1134.

Walker, A. K.; Soo, K. Y.; Sundaramoorthy, V.; Parakh, S.; Ma, Y.; Farg, M. A.; et al. (2013). ALSassociated TDP-43 induces endoplasmic reticulum stress, which drives cytoplasmic TDP43 accumulation and stress granule formation. PLoS One 8:e81170. 10.1371/journal.pone.0081170

Walsh, M. J.; Cooper-Knock, J.; Dodd, J. E.; Stopford, M. J.; Mihaylov, S. R.; Kirby, J.; et al. (2015). Decoding the pathophysiological mechanisms that underlie RNA dysregulation in neurodegenerative disorders: a review of the current state of the art. Neuropathology and Applied Neurobiology 41(2): 109-134.

Weids, A. J.; Grant, C. M. (2014). The yeast peroxiredoxin Tsa1 protects against proteinaggregate-induced oxidative stress. Journal of Cell Science 127(6): 1327-1335.

Weir, M. L.; Xie, H.; Klip, A.; Trimble, W. S. (2001). VAP-A binds promiscuously to both v- and tSNAREs. Biochem Biophys Res Commun. 286(3): 616-21.

Wijesekera, L. C.; Leigh, P. N. (2009). Amyotrophic lateral sclerosis. Orphanet J Rare Diseases 4 (3): 3.

Wu, H.; Ng, B. S. H.; Thibault, G. (2014). Endoplasmic reticulum stress response in yeast and 
humans. Bioscience Reports 34(4) e00118.

Xie, Z.; Klionsky, D. J. (2007). Autophagosome formation: Core machinery and adaptations. Nat Cell Biol. 9: 1102-1109.

Yang, Z.; Klionsky, D. J. (2010). Eaten alive: a history of macroautophagy. Nature Cell Biology 12(9): 814-822.

Yen, A. A.; Simpson, E. P.; Henkel, J. S.; Beers, D. R.; Appel, S. H. (2004). HFE mutations are not strongly associated with sporadic ALS. Neurology 2004; 62: 1611-1612

Yoshida, H.; Matsui, T.; Yamamoto, A.; Okada, T.; Mori, K. (2001). XBP1 mRNA is induced by ATF6 and spliced by IRE1 in response to ER stress to produce a highly active transcription factor. Cell 107: 881-891.

Zaldivar, T.; Gutierrez, J.; Lara, G.; Carbonara, M.; Logroscino, G.; Hardiman, O. (2009). Reduced frequency of ALS in an ethnically mixed population: a population-based mortality study. Neurology 72(19): 1640-1645.

Zhan, L.; Xie, Q.; Tibbetts, R. S. (2015). Opposing roles of p38 and JNK in a Drosophila model of TDP-43 proteinopathy reveal oxidative stress and innate immunity as pathogenic components of neurodegeneration. Hum. Mol. Genet. 24: 757-772. 